Matheus Levi Tajra Feitosa

Transplante heterólogo de células-tronco mesenquimais em ovinos com osteonecrose da cabeça do fêmur induzida

São Paulo

2008 
Matheus Levi Tajra Feitosa

\section{TRANSPLANTE HETERÓLOGO DE CÉLULAS-TRONCO MESENQUIMAIS EM OVINOS COM OSTEONECROSE DA CABEÇA DO FÊMUR INDUZIDA}

Dissertação apresentada ao Programa de PósGraduação em Anatomia dos Animais Domésticos e Silvestres da Faculdade de Medicina Veterinária e Zootecnia da Universidade de São Paulo para obtenção do título de Mestre em Ciências

\section{Departamento:}

Cirurgia

Área de Concentração:

Anatomia dos Animais Domésticos e Silvestres

Orientador:

Prof. Dr. Carlos Eduardo Ambrósio

São Paulo 
Autorizo a reprodução parcial ou total desta obra, para fins acadêmicos, desde que citada a fonte.

DADOS INTERNACIONAIS DE CATALOGAÇÃO-NA-PUBLICAÇÃO

(Biblioteca Virginie Buff D’Ápice da Faculdade de Medicina Veterinária e Zootecnia da Universidade de São Paulo)

Feitosa, Matheus Levi Tajra

Transplante heterólogo de células-tronco mesenquimais em ovinos com osteonecrose da cabeça do fêmur induzida / Matheus Levi Tajra Feitosa. - São Paulo : M. L. T. Feitosa, 2008.

$67 \mathrm{f}$. : il.

Dissertação (mestrado) - Universidade de São Paulo. Faculdade de Medicina Veterinária e Zootecnia. Departamento de Cirurgia, 2008.

Programa de Pós-Graduação: Anatomia dos Animais Domésticos e Silvestres.

Área de concentração: Anatomia dos Animais Domésticos e Silvestres.

Orientador: Prof. Dr. Carlos Eduardo Ambrósio.

1. Ovinos. 2. Articulação coxofemoral. 3. Células-tronco. 4. Fêmur. I. Título. 


\section{UNIVERSIDADE DE SÃO PAULO \\ Faculdade de Medicina Veterinária e Zootecnia}

Comissão Bioética

\section{CERTIFICADO}

Certificamos que o Projeto intitulado "Transplante autólogo de células tronco mesenquimais da medula óssea em ovinos com osteonecrose da cabeça do fêmur induzida", protocolado sob o n¹003/2006, utilizando 12 (doze) ovelhas, sob a responsabilidade do Dr. Carlos Eduardo Ambrósio (Pós-Doutorando do VCI), está de acordo com os princípios éticos de experimentação animal da Comissão de Bioética da Faculdade de Medicina Veterinária e Zootecnia da Universidade de São Paulo e foi aprovado em reunião de 17/04/07.

(We certify that the Research "Autologous transplant of mesenchymal stem cells in sheeps with osteonecrosis of femoral head induced", protocol number 1003/2006, utilizing 12 (twelve) sheeps, under the responsibility of Dr. Carlos Eduardo Ambrósio, agree with Ethical Principles in Animal Research adopted by Bioethic Commission of the School of Veterinary Medicine and Zootechny of University of São Paulo and was approved in the meeting of the day 04/17/2007).

São Paulo, 20 de abril de 2007

Profa. Dra. Denise Tabacchi Fantoni

Vice-Presidente da Comissão de Bioética

FMVZ/USP 


\section{FOLHA DE AVALIAÇÃO}

Nome: FEITOSA, Matheus Levi Tajra

Título: Transplante heterólogo de células-tronco mesenquimais em ovinos com osteonecrose da cabeça do fêmur induzida

Dissertação apresentada ao Programa de PósGraduação em Anatomia dos Animais Domésticos e Silvestres da Faculdade de Medicina Veterinária e Zootecnia da Universidade de São Paulo para obtenção do título de Mestre em Ciências

Data: $/ 2008$

Banca Examinadora

Prof.Dr. Instituição:

Assinatura Julgamento:

Prof.Dr. Instituição:

Assinatura Julgamento:

Prof.Dr. Instituição:

Assinatura Julgamento: 


\section{Dedicatória}

A minha família, pela educação concedida, carinho e amor por toda a vida:

Aos meus pais Silvia Maria Nogueira Tajra e Airtom Gondim Feitosa,

Aos meus irmãos Airtom José Tajra Feitosa, Eduardo Arthur Tajra Feitosa e Lídia Tajra Feitosa,

Aos sobrinhos Arthur e Natália,

A minha avó materna Maria do Rosário Nogueira Tajra,

A José dos Santos Carvalho Júnior. 


\section{Agradecimentos}

A CAPES e FAPESP pelo apoio financeiro concedido a esse experimento.

Ao Prof. Dr. Carlos Eduardo Ambrósio e Prof $^{\mathrm{a}} \mathrm{Dr}^{\mathrm{a}}$ Maria Angélica Miglino pela oportunidade concedida.

Ao Prof. Dr. João Flávio Panattoni Martins, pela concessão de espaço físico e apoio irrestrito para a realização deste experimento no Centro Universitário da Fundação de Ensino Octávio Bastos - UNIFEOB.

A Prof ${ }^{a} \mathrm{Dr}^{\mathrm{a}}$ Patrícia Cristina Baleeiro Beltrão Braga, pela ajuda essencial no processo de rastreamento das células e pelas extensivas explicações quanto ao processo de transdução viral.

Ao Prof. Dr. Eduardo Harry Birguel Júnior, pela concessão do espaço físico, palavras de apoio constantes e por nunca negar auxílio quando Ihe foi solicitado.

A Prof a Maria Eugenia Leite Duarte do Instituto de TraumátoOrtopedia (INTO) pelo pronto atendimento quando foi necessário o apoio.

A todos meus amigos de pós-graduação, em especial aos companheiros Marcello Machado, Alex Sander Dias Machado, Thaís Peixoto Gaiad Machado, André Gatti, Simone Pereira, Claúdia Kanashiro, Carlos 
Alberto Pereira Sarmento, Marcelo Mendes, Renato Gerger, Ricardo Guerra, Marina Brito, Angélica Oliveira, Marina Moreira e Carlos Magenta.

A todos do canil GRMD, em especial a Marina Brólio, Danielle Martins e Alida Abatemarco, pelo companheirismo e discussões enriquecedoras de casos clínicos.

Ao Augusto funcionário do canil GRMD e aos funcionários da Anatomia Índio, Ronaldo, Sandra, Ronaldo, Diogo, João e Raimundo.

A Maicon e Jaqueline, secretários do setor de anatomia, ajudando sempre que necessário.

A Cristiane Venceslau, pela paciência e ajuda constante no processo de separação e cultivo das células-tronco.

A André Franciolli, pela ajuda inestimável na histologia deste trabalho.

Ao grande amigo e companheiro de pós-graduação Leandro Fadel, por me acompanhar em meus devaneios e em todo o processo de construção deste trabalho.

Aos eternos amigos Carlos Eduardo Cruz Pinto e Flávio Ribeiro Alves, companheiros de república.

Aos amigos João Paulo Elsen Salt, Ewaldo Matos Júnior e Raimundo Barreto pelos momentos de descontração. 
Aos ex-residentes da Clínica de Ruminantes da FMVZ-USP, Carol, Rubens e Marjorie, alguns já pós-graduandos dessa mesma instituição.

Ao amigo de longa data, Leonardo Frasson, e ao amigo recente Pedro Paulo Machado pela ajuda ao final deste experimento e momentos de descontração.

A minha namorada Viviane Letícia Martins, pelo amor, carinho, compreensão e apoio de todas as formas, sem você eu não teria conseguido.

E a todos os amigos que direta ou indiretamente ajudaram no processo de conclusão deste trabalho. 


\section{RESUMO}

FEITOSA, M. L. T. Transplante heterólogo de células-tronco mesenquimais em ovinos com osteonecrose da cabeça do fêmur induzida. [Heterologous Transplant of Bone Marrow Mesenchymal Stem Cells in Ovine With Osteonecrosis of The Femoral Head Induced]. 2008. 67 f. Dissertação (Mestrado em Ciências) - Faculdade de Medicina Veterinária e Zootecnia, Universidade de São Paulo, São Paulo, 2008.

A Osteonecrose da cabeça do fêmur (ONCF) é uma patologia degenerativa que pode levar ao colapso da cabeça do fêmur tendo como conseqüência a necessidade de substituição da articulação coxofemoral. O objetivo principal no tratamento da ONCF é preservar a articulação coxofemoral e não substituí-la. Estudos realizados em pacientes humanos com ONCF demonstraram que os níveis de atividade e $o$ número de células mesenquimais nos compartimentos hematopoiéticos e estromais da medula óssea estão deprimidos. Estes achados indicam a possibilidade da utilização de células-tronco mesenquimais (MSC) nas lesões necróticas da cabeça do fêmur. O presente trabalho propõe a utilização da terapia celular com MSC da medula óssea de ovinos e polpa dentária humana em 8 ovinos com ONCF induzida pela injeção intra-óssea de etanol, além da avaliação da reestruturação óssea através da microscopia de luz, e rastreamento das células transplantadas. Dois animais foram eutanasiados com 6 semanas após a indução da lesão e foram transplantadas as células-tronco mesenquimais em 4 animais, e realizada a descompressão central em 2 outros animais. Com dez semanas foram eutanasiados os animais restantes. O sucesso do transplante da medula óssea foi confirmado pela expressão do gene repórter LacZ na cabeça do fêmur dos animais transplantados macroscopicamente. A análise histológica evidenciou maior processo regenerativo na cabeça do fêmur do animal experimental submetido à terapia com células-tronco da polpa dentária imatura humana.

Palavras-Chave: Ovinos. Articulação coxofemoral. Células-tronco. Fêmur. 


\section{ABSTRACT}

FEITOSA, M. L. T. Heterologous Transplant of Bone Marrow Mesenchymal Stem Cells in Ovine With Osteonecrosis of The Femoral Head Induced [Transplante heterólogo de células-tronco mesenquimais em ovinos com osteonecrose da cabeça do fêmur induzida]. 2008. 67 f. Dissertação (Mestrado em Ciências) - Faculdade de Medicina Veterinária e Zootecnia, Universidade de São Paulo, São Paulo, 2008.

The osteonecrosis of femoral head (ONFH) is a degenerative disease that can lead to the collapse of the femoral head and necessity of total hip replacement. The main objective in the treatment of ONFH is to preserve the hip and not replace it. Studies in human patients with ONFH demonstrated that levels of activity and the number of mesenchymal cells in the hematopoietic and bone marrow stromal compartments are depressed. These findings indicate the possibility of the use of mesenchymal stem cells (MSC) in necrotic lesions on the head of the femur. This research proposes the use of cell therapy with MSC from ovine bone marrow and immature human dental pulp stem cell in ovine ONCF induced by intraosseous injection of ethanol, in addition, the assessment of bone restructuring by light microscopy and tracking of the transplanted cells. Two animals were euthanasied with 6 weeks after the induction of injury, and were transplanted mesenchymal stem cells in 4 animals, and held the central decompression in 2 other animals. After ten weeks were euthanasied the remaining animals. The successful of the bone marrow transplantation was confirmed by the macroscopic expression of the LacZ gene reporter in the femoral head of animals transplanted. The histological analysis showed an advanced regenerative process in the femoral head in the animal using human immature dental pulp stem cell.

Key-Words: Ovine. Hip joint. Stem cell. Femur. 


\section{SUMÁRIO}

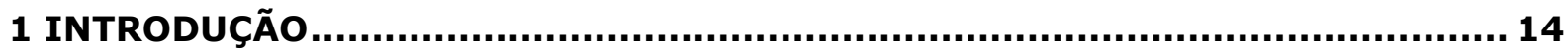

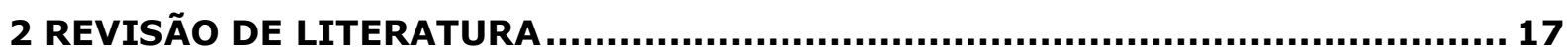

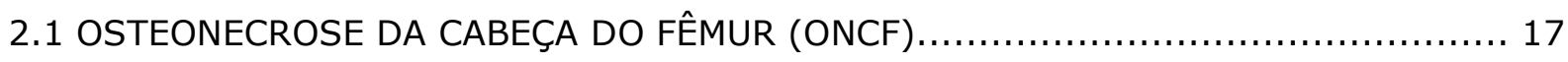

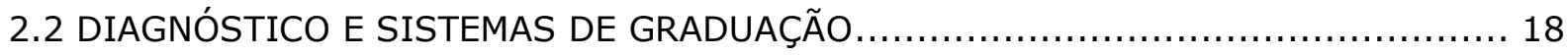

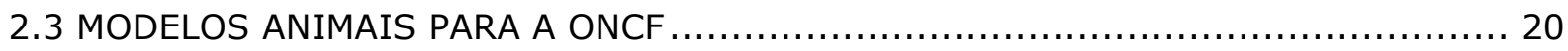

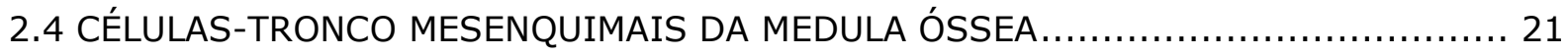

2.5 CÉLULAS-TRONCO MESENQUIMAIS DA POLPA DENTÁRIA HUMANA $\ldots \ldots \ldots \ldots \ldots \ldots \ldots . \ldots \ldots$

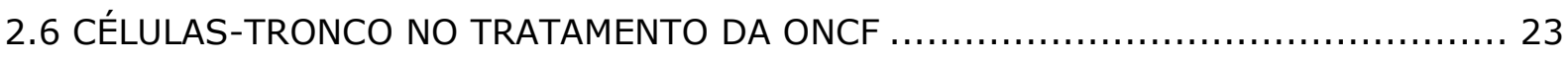

2.7 USO DE VETORES RETROVIRAIS NO RASTREAMENTO PÓS-TRANSPLANTE ............ 25

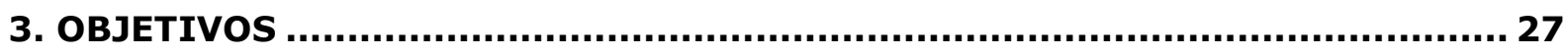

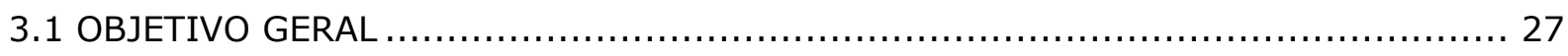

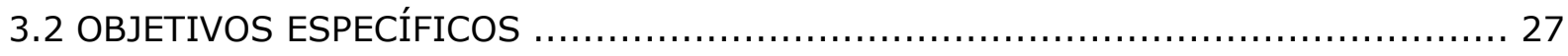

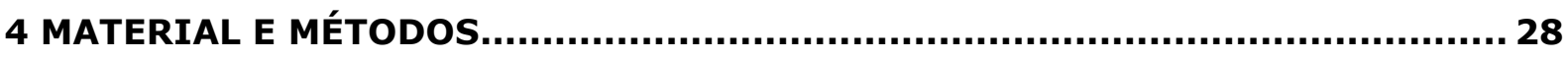

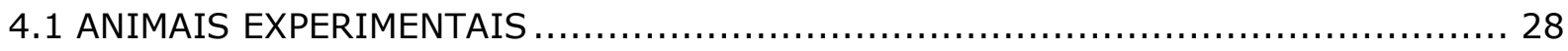

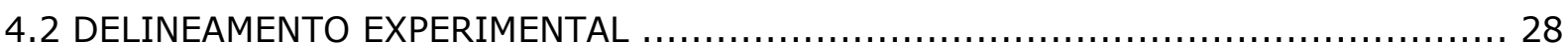

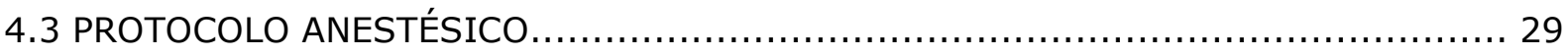

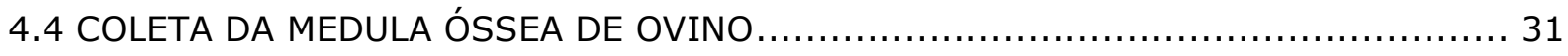

4.5 ISOLAMENTO E CULTIVO DAS CÉLULAS-TRONCO MESENQUIMAIS DA MEDULA

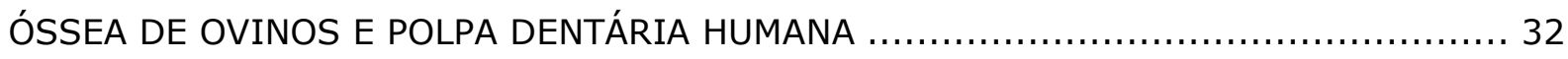

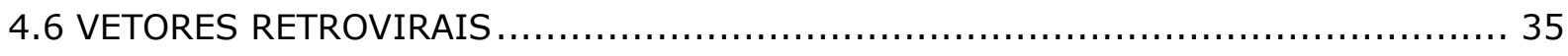

4.6.1 Cultivo de células de linhagens estabelecidas ................................. 35 
4.6.3 Análise da expressão dos genes exógenos (lacz) nas células tronco mesenquimais transduzidas previamente à transplante nos ovinos

4.6.4 Preparação de células-tronco transduzidas para transplante nos animais.

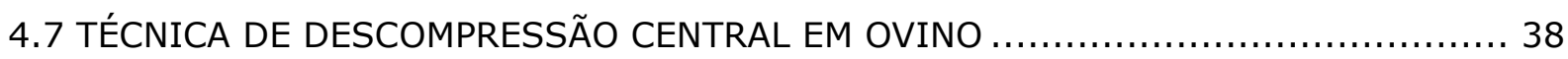

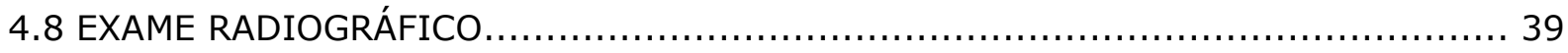

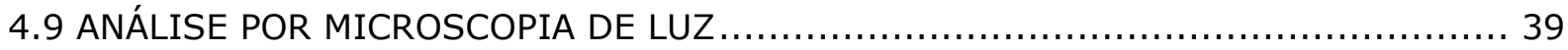

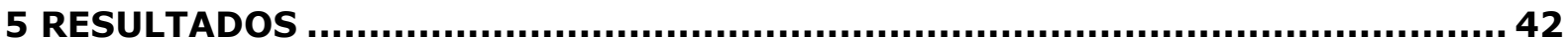

5.1 CULTIVO DAS CÉLULAS-TRONCO MESENQUIMAIS DA MEDULA ÓSSEA DE OVINOS 42

5.2 REALIZAÇÃO DA TÉCNICA DE DESCOMPRESSÃO CENTRAL EM OVINOS .... 45

5.3 ANÁLISE DA EXPRESSÃO DO GENE REPÓRTER LACZ NAS CÉLULAS-TRONCO

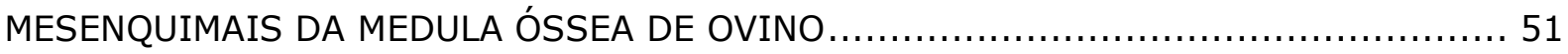

5.4 ANÁLISE DA EXPRESSÃO DO GENE REPÓRTER LACZ NAS CÉLULAS-TRONCO

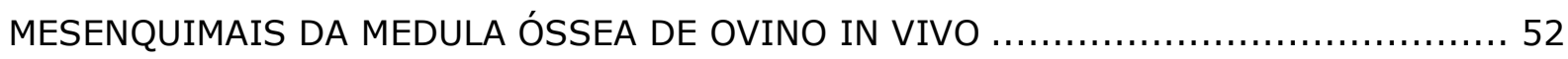

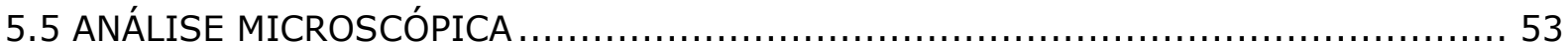

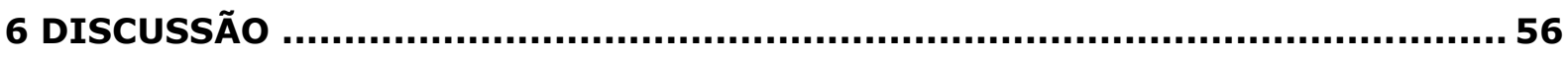

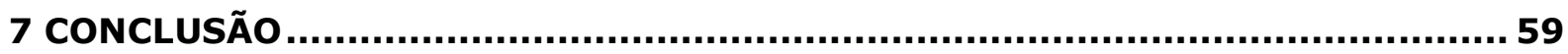

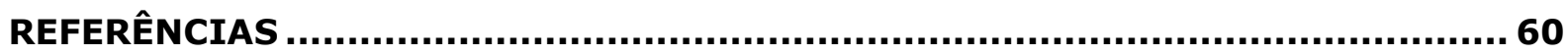




\section{INTRODUÇÃO}

A Osteonecrose da cabeça do fêmur (ONCF) é uma patologia degenerativa que pode levar ao colapso da cabeça do fêmur tendo como conseqüência a necessidade de substituição da articulação coxofemoral. O objetivo principal no tratamento da ONCF é preservar a articulação coxofemoral e não substituí-la.

A doença apresenta várias terminologias, tais como necrose asséptica da cabeça do fêmur, necrose isquêmica ou infarto ósseo. No ano de 1993, a Association Research Circulation Osseous (ARCO), tendo como objetivo padronizar a nomenclatura e facilitar a classificação das necroses ósseas definiu a necrose do osso como osteonecrose, estabelecendo ainda, critérios para sua classificação.

A ONCF é considerada multifatorial e sua patogenia ainda é desconhecida. Sabe-se que a doença apresenta como fatores predisponentes à ingestão abusiva de bebidas alcoólicas, e o uso prolongado de drogas esteroidais em pacientes com doenças imunomediadas (WANG et al., 2005).

O procedimento conservativo mais comumente utilizado para o tratamento dos estágios iniciais da ONCF é a descompressão central com enxertos vascularizados ou não vascularizados (ISRAELITE et al., 2005). Este método vem sendo realizado há três décadas, mostrando resultados controversos (FICAT et al., 1985; YOON et al., 2001).

Vários modelos foram utilizados para mimetizar a doença em humanos, visando à realização de tentativas terapêuticas que preservem a articulação coxofemoral. A maioria destes modelos foi baseada na teoria da "supressão vascular", induzidos cirurgicamente, ou através de sobredoses de drogas esteroidais (BOSS; MISSLEVICH, 2003).

As opções de tratamento propostas até então, só apresentam resultados viáveis em estágios subclínicos da doença. Entretanto, os 
modelos estudados levam ao total colapso da cabeça do fêmur, onde somente procedimentos de substituição da cabeça do fêmur podem ser empregados (YOON et al., 2001; WANG et al. 2005).

O modelo proposto por Manggold (2002) apresenta características semelhantes às encontradas nos estágios iniciais de osteonecrose em humanos, com manutenção da cartilagem articular intacta, preservação da estrutura trabecular interna e da macrocirculação. O presente modelo apresenta ainda dimensões anatômicas mais próximas ao humano, o que torna válida a sua utilização como modelo experimental em terapêuticas na ONCF.

Estudos realizados em pacientes com ONCF demonstraram que os níveis de atividade e $o$ número de células mesenquimais nos compartimentos hematopoiéticos e estromais da medula óssea estão deprimidos em pacientes com ONCF (HERNIGOU et al., 1999). Estes achados indicam a possibilidade da utilização de células-tronco mesenquimais nas lesões necróticas da cabeça do fêmur (GANGJI et al., 2004).

As células-tronco mesenquimais (MSC-Mesenchymal Stem Cells) da medula óssea apresentam grande potencial para uso em terapia celular e gênica, em virtude da facilidade de obtenção do próprio paciente, além de facilidade de expansão in vitro eliminando problemas relacionados à rejeição com xeno-enxertos (BIANCO et al., 2001).

Apesar do uso da terapia celular na ONCF já apresentar resultados satisfatórios na clínica em humanos (GANGJI et al., 2007), os testes clínicos em pacientes transplantados com células-tronco são divergentes quanto sua eficácia após alguns anos de acompanhamento, existindo pouca informação sobre a quantidade de células sobreviventes após transplante, e como de fato estas células ajudam no processo regenerativo (HASSAN; EL-SHEMEMY, 2004).

A polpa dentária de dentes decíduos surge como fonte alternativa para obtenção de MSC, apresentando grande potencial para uso em 
ortopedia, devido a características únicas como: fácil obtenção de material para cultivo celular, extração eficiente, alta habilidade de diferenciação e boa interatividade com biomateriais (D'AQUINO et al., 2008). Além disso, sua eficácia de diferenciação é evidenciada para vários tecidos corpóreos e recentemente especifico para músculos (KERKIS et al., 2006; KERKIS et al., 2008), relacionado a nosso grupo de pesquisa, no tratamento da distrofia muscular no modelo canino, Golden Retriever Muscular Dystrophy.

O presente trabalho propõe a utilização da terapia celular com MSC da medula óssea de ovinos e polpa dentária humana (hIDPSC - Human Immature Dental Pulp Stem Cell) em ovinos com ONCF induzida pela injeção intra-óssea de etanol, além da avaliação da reestruturação óssea através da microscopia de luz, e rastreamento das células transplantadas. O advento do uso das células humanas é devido ao rastreamento facilitado dos cromossomos humanos dentro do organismo ovino comprovando assim, a eficácia do transplante e diferenciação óssea, com vistas à grande quantidade de marcadores específicos para humanos no rastreamento pós-transplante, fato este pouco evidente para marcadores referentes à espécie ovina. 


\section{REVISÃO DE LITERATURA}

A revisão de literatura será disposta em tópicos individualizados para facilitar a compreensão do trabalho dispondo de uma vista geral sobre os assuntos.

\subsection{OSTEONECROSE DA CABEÇA DO FÊMUR (ONCF)}

Necrose asséptica da cabeça do fêmur, necrose avascular, necrose isquêmica, ou infarto ósseo são algumas das terminologias utilizadas para designar a síndrome clínica aqui descrita como osteonecrose da cabeça do fêmur (ONCF). O termo necrose asséptica foi primeiramente utilizado para diferenciar esta doença do seqüestro ósseo decorrente das infecções. Os termos necrose avascular, necrose isquêmica ou infarto ósseo sugerem uma etiologia e patogênese uniforme. Entretanto, a patogênese desta síndrome permanece desconhecida, apresentando causas variadas, havendo a necessidade do uso de um termo mais neutro para denominação desta doença (SUGANO et al., 2002).

No Ano de 1993, a Association Research Circulation Osseous (ARCO) propôs a busca de terminologias e definições para a ONCF, tendo como objetivo padronizar os termos utilizados. O osso foi considerado como um órgão que consiste na reunião de tecidos mineralizados. A necrose óssea foi definida como uma doença que causa a morte do osso, portanto, foi designada de osteonecrose.

A ONCF é um processo degenerativo progressivo que leva ao colapso do osso e a destruição da cartilagem, com sérias conseqüências clínicas (MAGNUSSEN et al., 2005). É uma doença tanto de interesse clínico, quanto econômico, sendo responsável pela internação de 
aproximadamente vinte e mil pacientes por ano nos EUA (BEJAR et al., 2005).

Objetivando estudar a patogênese do uso de esteróides na ONCF, Bekler et al. (2007) utilizaram 30 ratos divididos em 3 grupos: o primeiro grupo teve a ONCF induzida através da administração de soro humano, um segundo grupo tratado com corticóides e um terceiro grupo controle, onde não foram realizados tratamentos. Os autores concluíram através dos achados histológicos, que apesar de não ser a principal causa da ONCF, a terapia com esteróides aumenta consideravelmente o risco da doença.

\subsection{DIAGNÓSTICO E SISTEMAS DE GRADUAÇÃO}

Hauzer et al. (1989) avaliaram a necessidade e eficácia da ressonância magnética no diagnóstico de 49 articulações humanas com suspeitas de ONCF com base em radiografias, tomografia computadorizada, cintilografia óssea e ressonância magnética. Os resultados dos testes diagnósticos foram comparados com os achados histopatológicos de biópsias transtrocantéricas da cabeça e colo femoral das articulações. A ressonância magnética foi precisa em todas as articulações com achados patológicos condizentes com ONCF.

Huffman et al. (2007) estudaram as alterações no líquido sinovial de cães com ONCF induzida criocirurgicamente, confirmando que a ONCF está também associada com alterações na glicose e no lactato do líquido sinovial, quando comparados aos animais experimentais com os animais controle.

Gardeniers (1993) descreveu o sistema de gradação da ARCO para osteonecrose da cabeça do fêmur. Segundo a ARCO, a ONCF pode ser 
classificada em estágio-0, quando todas as técnicas de diagnóstico não revelam alterações; estágio-I, quando os achados radiográficos e de tomografia computadorizada aparentem normalidade, entretanto, a cintilografia, ou a ressonância magnética apresenta sinais clínicos; estágio-II, as lesões estão presentes nos exames radiográficos e na tomografia computadorizada, não havendo fratura subcondral; estágio III, fratura subcondral; estágio IV, progressão para osteoartrite e degeneração da cartilagem articular.

Magnussen et al. (2005), pesquisaram a degeneração da cartilagem pós-colapso na osteonecrose da cabeça do fêmur, em trinta e sete cabeças femorais frescas. Os autores não encontraram evidência de que o tamanho da lesão está associada a uma maior degeneração da cartilagem articular, nem relação entre os achados radiográficos e possíveis alterações histológicas ou mecânicas. Estes resultados sugerem a possibilidade da utilização de técnicas que preservem a articulação coxofemoral, mesmo em estágios avançados, desde que a cartilagem articular esteja íntegra.

Mont et al. (2006) realizaram análise sistemática de todos os sistemas de classificação vigentes para o diagnóstico da ONCF, tendo dois objetivos principais: dar um relato dos métodos de gradação e diagnóstico mais utilizados e comparar os métodos com base na similaridade dos achados usados como base diagnóstica. Os autores concluíram que os sistemas de Ficat (1985), Steinberg et al. (1995), ARCO e da Japanese Orthopaedic Association são os 4 sistemas de classificação mais utilizados na gradação da ONCF, e que todos esses sistemas apresentam diversas similaridades entre eles. 


\subsection{MODELOS ANIMAIS PARA A ONCF}

Partindo do princípio que a patogênese da ONCF é desconhecida, é difícil definir um critério para a realização de um modelo animal viável. As características dos estágios precoces da osteonecrose da cabeça do fêmur incluem necrose intra-óssea com estrutura trabecular intacta, manutenção da cartilagem articular e da macrocirculação (MANGGOLD et al., 2002).

Os modelos animais são indispensáveis para o entendimento e sucesso no tratamento das modalidades de ONCF, em adultos e em crianças com a síndrome de Legg Calvé Perthes. Entretanto, a maioria dos modelos utilizados atualmente, leva em consideração apenas a teoria da "supressão vascular" (CONZEMIUS et al., 2002; BEJAR et al., 2005). Esta é comumente induzida cirurgicamente, ou através da utilização de drogas esteroidais (BOSS \& MISSELEVICH, 2003).

A resolução espontânea da ONCF pode ocorrer, dependendo basicamente do tamanho da lesão e do estágio em que se encontra a patologia. Os sinais de resolução espontânea podem demorar até um ano até sua constatação (CHENG et al., 2004).

Manggold et al. (2002) propôs um modelo animal de necrose da cabeça do fêmur através da injeção intra-óssea de etanol puro no centro da cabeça do fêmur, em dez ovinos. A necrose induzida apresenta sinais clínicos semelhantes aos encontrados na ONCF de estágios I e II, preservando as características anatômicas do osso, havendo a possibilidade de cicatrização espontânea em um período de 12 semanas. Além disso, o modelo obtido apresenta tamanho considerável, mais próximo da anatomia humana. Todos os animais apresentaram osteonecrose da cabeça do fêmur.

Objetivando estudar os metabólitos no líquido sinovial de animais com ONCF, Huffman et al. (2007) induziram a lesão em cães utilizando a 
técnica de descompressão central associada à instilação de nitrogênio líquido diretamente na cabeça do fêmur dos animais.

\subsection{CÉLULAS-TRONCO MESENQUIMAIS DA MEDULA ÓSSEA}

Friedenstein et al. (1976) foram os primeiros pesquisadores a observar que a medula óssea continha células com formato de fibroblastos, denominadas MSC, que eram capazes de se diferenciar em outros tipos celulares. Desde então, vários estudos tem avançado no entendimento do fenótipo, fisiologia, potencial de diferenciação e possíveis aplicações clínicas dessas células, que podem ser expandidas in vitro, pois aderem em placas de cultura, e proliferam, formando colônias celulares com formato de fibroblastos (PITTENGER et al., 1999).

As MSC da medula óssea são um tipo celular promissor para uso na medicina regenerativa, devido à capacidade desse tipo celular de se diferenciar em diversos tecidos, tais como osso, cartilagem, gordura, tendões e estroma (PROCKOP, 1997).

As células-tronco adultas substituem e reparam tecidos lesionados. Embora estas células tenham sido isoladas e expandidas em cultivo, o seu uso em estratégias terapêuticas requer tecnologias ainda não aperfeiçoadas. A adequação dessas células com biomateriais como veículo, e o estudo dos fatores de crescimento associado à terapia celular são desafios a serem suplantados (CAPLAN, 2005).

Rhodes et al. (2004) objetivando estudar a heterogenicidade e proliferação das MSC de carneiros utilizou 28 ovelhas de diferentes raças, com idade variando de 4 até 8 meses. Os autores usaram o aspecto aderente das células como forma de isolamento das células. A identidade das células cultivadas como progenitoras de linhagem mesenquimal foi 
definida pela capacidade de diferenciação em células com fenótipo de osteblastos e condrócitos, quando cultivadas em meios específicos para osso e cartilagem. Segundo os autores, a idade e a raça dos animais não foram fatores significantes para a proliferação celular.

Mrugala et al. (2008), realizaram a caracterização completa das MSC da medula óssea de carneiros. Os autores usaram três critérios para classificação das células: Aderência ao plástico, perfil fenotípico (positivas para CD44, CD105 e vimentina e negativas para CD34 e CD45) e diferenciação em três linhagens: osso, gordura e cartilagem.

\subsection{CÉLULAS-TRONCO MESENQUIMAIS DA POLPA DENTÁRIA HUMANA}

A polpa dentária humana é uma fonte de MSC recentemente descoberta, e com possibilidades terapêuticas promissoras.

Gronthos et al. (2000) isolaram uma população clonogênica e proliferativa de células da polpa dentária humana. Os autores caracterizaram imunofenotipicamente estas células e compararam as MSC da polpa dentária com as MSC de medula óssea, julgando haver semelhanças marcantes entre as mesmas.

Gronthos et al. (2002) estudaram a capacidade auto regenerativa, capacidade de diferenciação em multi-linhagens e a eficiência clonogênica das células-tronco da polpa dentária em humanos. Os autores relataram a capacidade de diferenciação destas células em adipócitos e células com aspecto neural.

Kerkis et al. (2006) relataram o isolamento e caracterização, através de diversos marcadores de células-tronco de origem embrionária, de células-tronco de polpa dentária imatura. Os autores diferenciaram essas células em músculo liso e estriado, osso, cartilagem e neurônios em 
condições de cultivo pré-definidos, sugerindo a utilização destas células em ensaios pré-clínicos.

Otaki et al. (2007) injetaram células-tronco de polpa dentária humana no subcutâneo de ratos imunocomprometidos, usando como veículo pó de hidroxiapatita e fosfato tricálcico, retirando os implantes com 7 e 15 semanas. Os autores relatam a formação de osso ao invés de dentina no subcutâneo dos ratos, e concluem que a polpa dentária humano deve ser utilizada com finalidades terapêuticas para recuperação de tecidos danificados.

\subsection{CÉLULAS-TRONCO NO TRATAMENTO DA ONCF}

Tendo em vista que a preservação da articulação é um objetivo desejado, os procedimentos conservativos para o tratamento da ONCF são os de eleição para os estágios iniciais da ONCF (MAGNUSSEN al., 2005). Dentre as opções de tratamento que preservam a articulação, estão inclusas a descompressão central, a descompressão central associada aos enxertos ósseos vascularizados e não vascularizados, transplante autólogo de células tronco da medula óssea e as ondas de choque extracorpóreos (FICAT, 1985; GANGJI et al., 2005; WANG et al., 2005; MARCINIAK et al., 2008).

A descompressão central com ou sem enxertos ossos é o método mais utilizado nos estágios iniciais da ONCF (ISRAELITE et al., 2005). Entretanto, este procedimento já é realizado há três décadas, e sua eficácia é controversa (FICAT, 1985; YOON et al., 2001).

Segundo Hernigou et al. (1999), os níveis de atividade e o número de células-tronco mesenquimais, tanto nos compartimentos hematopoiético quanto estromal da medula óssea, têm se mostrado 
deprimido em pacientes com osteonecrose da cabeça do fêmur induzida por corticóides, sugerindo a necessidade de terapêuticas voltadas para a terapia celular.

A medula óssea é um reservatório de células-tronco e progenitoras pluripotentes para tecidos mesenquimatosos. Quando as células-tronco mesenquimais são isoladas e expandidas na presença do fator-2 de crescimento de fibroblastos, a percentagem de células hábeis para a diferenciação em linhagens osteogênicas, condrogênicas e adipogênicas é grande (CANCEDDA et al., 2003).

Gangji et al. (2005), instituiu o tratamento da ONCF com implante autólogo de células da medula óssea em dezoito articulações divididas em dois grupos. Em um grupo foi realizada somente a descompressão central, sendo este o grupo controle, e no outro grupo a descompressão central foi associada com o implante de células autólogas da medula óssea. Após quatro meses de análise cinco das oito articulações progrediram para o terceiro estágio-III de osteonecrose (fratura subcondral), enquanto que o mesmo aconteceu em apenas uma articulação do grupo submetido ao implante. Esses achados estimulam a realização de novos estudos no campo das células-tronco, incluindo o uso de sub-populações de células progenitoras com potencial terapêutico.

Dezoito pacientes com ONCF grau 1 e 2 da escala da ARCO foram submetidos à técnica de descompressão central. Em 10 desses pacientes a descompressão central foi associada com 0 uso de células-tronco mononucleares, e em 8 pacientes foi realizada somente a descompressão. Um estudo cego do acompanhamento de 5 anos desses pacientes demonstrou que 4 dos pacientes pertencentes ao grupo controle necessitaram de substituição total da cabeça do fêmur, fato observado em apenas um paciente pertencente ao grupo experimental (GANGJI et al., 2007).

Seok-Jun Kim et al. (2008) utilizaram a descompressão central associada com a aplicação de osteoblastos cultivados a partir da medula 
óssea para o tratamento de um paciente com osteonecrose da cabeça do fêmur bilateral. A ressonância magnética do paciente confirmou estágio II da classificação de Ficat (1985) em ambos os membros. O membro esquerdo foi tratado com a descompressão central e enxerto ósseo autógeno, e o membro direito com descompressão central e osteoblatos oriundos de cultivo da medula óssea. Após cinco anos foi constatada total recuperação da cabeça do fêmur direita do paciente, e progressão da lesão na cabeça de fêmur do membro esquerdo, sugerindo a eficácia do tratamento com osteoblastos.

2.7 USO DE VETORES RETROVIRAIS NO RASTREAMENTO PÓSTRANSPLANTE

A evolução biotecnológica, através da engenharia genética, vem possibilitando o desenvolvimento de vetores para a transferência de genes cada vez mais seguros, de fácil produção em grande escala e eficientes nos processos de transfecção e transdução in vitro ou in vivo.

Pouca informação existe sobre como as células-tronco transplantadas de fato participam em um processo regenerativo, e quantas células de fato sobrevivem após transplante (HASSAN; ELSHEMEMY, 2004).

Hannouche et al., em 2007, relata que células-tronco mesenquimais de medula óssea transplantadas em tecido esquelético de camundongos foram capazes de expressar um gene repórter ( $L a C Z$ ) por mais de 4 semanas, além de reparem e vascularizarem o osso defeituoso in vivo.

Ueblacker et al. (2007) realizaram análise in vivo da transferência de gene retroviral para condrócitos utlizando colágeno como veículo para 
o tratamento de defeitos osteocondrais. Após 4 semanas de implante foi possível observar a expressão da $\beta$-galactosidase intra-articular na maioria dos condrócitos implatados através da fixação com X-Gal. 


\section{OBJETIVOS}

\subsection{OBJETIVO GERAL}

Avaliar histologicamente o efeito da terapia celular com célulastronco mesenquimais da medula óssea em ovinos com osteonecrose da cabeça do fêmur induzida experimentalmente.

\subsection{OBJETIVOS ESPECÍFICOS}

- Realizar a caracterização das células-tronco mesenquimais da medula óssea de ovinos;

- Efetivar a tranfecção gênica com LACZ em células de medula óssea de ovelhas;

- Injetar e rastrear as células injetadas para confirmar o sucesso do transplante celular;

- Fazer uma análise comparativa dos animais submetidos ao tratamento com os animais que só receberam o tratamento cirúrgico de descompressão central como tratamento.

- Usar células-tronco mesenquimais de humanos para validar o transplante através de rastreamento de cromossomos. 


\section{MATERIAL E MÉTODOS}

\subsection{ANIMAIS EXPERIMENTAIS}

Foram empregados oito carneiros machos da raça Santa Inês, com idade entre 18 a 24 meses, hígidos. Os animais foram mantidos na Clínica de Bovinos e Pequenos Ruminantes da FMVZ-USP e também parceria com o HOVET do Centro Universitário da Fundação de Ensino Octávio Bastos, em São João da Boa Vista, em duas baias de 12 metros quadrados, seis animais em cada baia. Foi fornecida alimentação à base de feno duas vezes ao dia e $200 \mathrm{~g}$ de ração peletizada por animal uma vez ao dia. Todos os animais foram mantidos sob as mesmas condições de manejo durante todo período experimental.

\subsection{DELINEAMENTO EXPERIMENTAL}

A lesão foi induzida utilizando a descompressão central com injeção de etanol em todos os animais. Seis semanas após a indução da lesão, foi repetida a técnica de descompressão central com células tronco mesenquimais de duas fontes distintas: células tronco mesenquimais da medula óssea de ovino (MOO) em dois animais, e células tronco mesenquimais da polpa dentária humana (hIDPSC) em mais dois animais constituindo o grupo experimental com quatro animais. Dois animais pertencentes ao grupo controle foram eutanasiados para confirmar histologicamente o sucesso da indução da ONCF com seis semanas após o 
procedimento de indução. O restante dos animais foram eutanasiados com 10 semanas a partir da lesão inicial, ou seja, com 4 semanas de lesão, foram efetuados os transplantes.

\subsection{PROTOCOLO ANESTÉSICO}

Os animais receberam jejum de sólidos de 24 horas e de líquidos de 12 horas. Após o jejum os animais foram pré-medicados com 0,3 $\mathrm{mg} / \mathrm{kg}$ de midazolam associado a $2 \mathrm{mg} / \mathrm{kg}$ de cloridrato meperidina por via intravenosa na mesma seringa (Figura $1 \mathrm{~A}$ ).

Após 5 minutos da realização da medicação pré-anestésica, os animais foram induzidos à anestesia com $3 \mathrm{mg} / \mathrm{kg}$ de propofol associado à $5 \mu \mathrm{g}$ de fentanil por via intravenosa, intubados com sonda endotraqueal de tamanho apropriado e mantido em anestesia com isofluorano (Figura 1BC).

Todos os procedimentos anestésicos foram realizados com monitoração cardíaca e oximetria de pulso (Figura 1D). Os animais submetidos à coleta de medula através da crista ilíaca receberam 0,2 $\mathrm{mg} / \mathrm{kg}$ de meloxicam e $25 \mathrm{mg} / \mathrm{kg}$ de dipirona sódica para analgesia imediata, mantida posteriormente com $0,1 \mathrm{~m} / \mathrm{kg}$ de meloxicam uma vez ao dia durante aproximadamente 5 dias. 

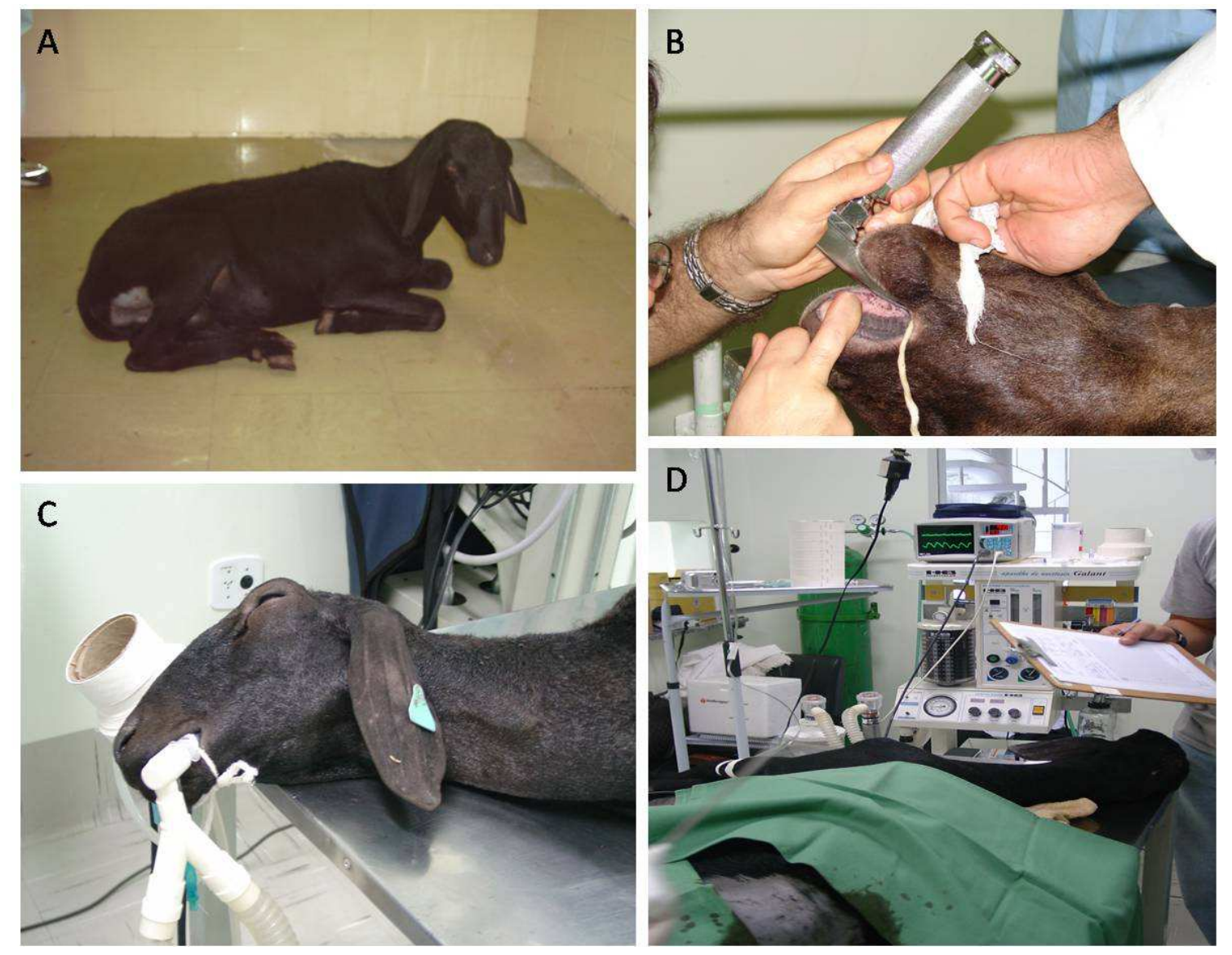

Figura 1 - Protocolo anestésico usado para coleta de medula e indução da osteonecrose da cabeça do fêmur em ovinos da raça Santa Inês. (A) Sedação com midazolam e meperidina por via intravenosa, (B) Animal após indução com cloridrato de cetamina, pronto para intubação, (C) Animal intubado com sonda endotraqueal $n^{\circ}$ 9.5, (D) Monitores e aparelho anestésico usados para anestesia dos ovinos

Os animais submetidos aos procedimentos de descompressão central, tanto para a indução da ONCF quanto para a injeção das células mesenquimais da medula óssea receberam $1 \mathrm{mg} / \mathrm{kg}$ de cetoprofeno e 25 $\mathrm{mg} / \mathrm{kg}$ de dipirona sódica, associada a $0,1 \mathrm{mg} / \mathrm{kg}$ de morfina por via epidural, mantida com $2 \mathrm{mg} / \mathrm{kg}$ de tramadol duas vezes ao dia, até a realização das eutanásias. A profilaxia antibacteriana, foi provida através de enrofloxacina na dose de $5 \mathrm{mg} / \mathrm{kg}$ uma vez ao dia até um total de cinco dias da realização dos procedimentos. 


\subsection{COLETA DA MEDULA ÓSSEA DE OVINO}

Para a coleta da medula óssea, a região da crista ilíaca foi devidamente tricotomizada e os animais permaneceram em decúbito lateral direito durante o procedimento, para prevenir a ocorrência de timpanismo (Figura 2A).

Após a realização da antissepsia com álcool e iodo-povidine (PVPI), a ponta da crista ilíaca era então palpada e uma cânula para biópsia de medula óssea (Biomedical ${ }^{\circledR}$ ) foi introduzida com a mão através da crista ilíaca no sentido crânio caudal com inclinação dorsal de aproximadamente $35^{\circ}$ (Figura 2B).

Foram aspirados de 15 até $30 \mathrm{ml}$ de medula em seringas de $5 \mathrm{ml}$ previamente lavadas com heparina sódica (Liquemine ${ }^{\circledR}$ ) (Figura 2C). Após a coleta da medula, era realizado um ponto simples no local da introdução da cânula. $O$ aspirado medular foi conduzido até o Laboratório de Células Tronco da FMVZ-USP, para realização dos protolos de isolamento e cultivo de células-tronco mesenquimais. 

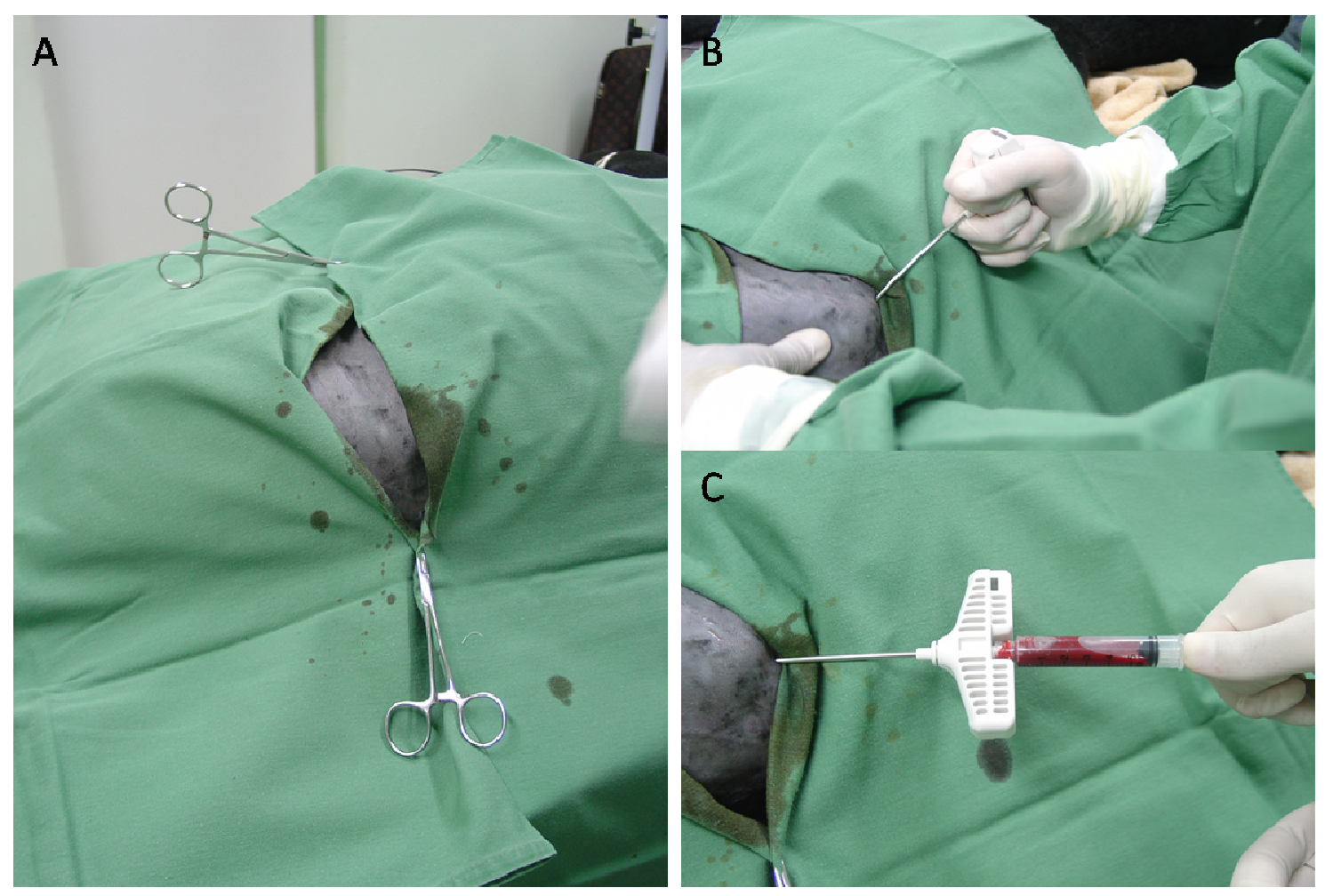

Figura 2 - Coleta de medula da crista ilíaca de ovino da raça Santa Inês sob anestesia geral inalatória em seringas de $5 \mathrm{ml}$ previamente heparinizadas. A - Região de coleta da medula na crista ilíaca após antissepsia de rotina. B - Introdução da cânula de medula óssea na crista ilíaca de ovino. C - Aspiração de medula óssea com seringas de $5 \mathrm{ml}$ previamente heparinizadas

\subsection{ISOLAMENTO E CULTIVO DAS CÉLULAS-TRONCO MESENQUIMAIS DA MEDULA ÓSSEA DE OVINOS E POLPA DENTÁRIA HUMANA}

A medula aspirada da crista ilíaca foi conduzida em seringas heparinizadas de $5 \mathrm{ml}$ até o Laboratório de Células Tronco da Faculdade de Medicina Veterinária e Zootecnia da Universidade de São paulo (FMVZUSP), onde a medula foi filtrada em malha de $100 \mu \mathrm{m}$ e diluída com PBS na proporção de $1: 3$.

Após essa diluição, a solução foi homogeneizada e foi adicionada solução para separação por gradiente de densidade (Ficoll, Histopaque ${ }^{\circledR}$ ) lentamente, centrifugando logo após a 2000 RPM durante 30 minutos a $20^{\circ} \mathrm{C}$. 
O pellet ressultante dessa centrifugação foi ressuspendido em PBS e centrifugado a 1000RPM, repetindo-se esse procedimento por 3x. Após esse procedimento, o pellet foi ressuspendido com meio de cultivo, e plaqueado em garrafas de $25 \mathrm{~cm}^{2}$ com densidade inicial de $2,0 \times 10^{5} / \mathrm{cm}^{2}$ contendo alpha minimum essential medium ( $\alpha$-MEM) suplementado com $15 \%$ de Soro Fetal Bovino (Invitrogen Corporation) e 1\% da solução total de antibiótico $(100 \mathrm{U} / \mathrm{ml}$ de penicilina e $100 \mu \mathrm{g} / \mathrm{ml}$ de estreptomicina).

Todas as culturas foram realizadas em estufa Thermo Electron Corparation (Forma Series II Water Jacketed $\mathrm{CO}_{2}$ Incubator HEPA Class 100) sob as condições de cultivo a $37^{\circ} \mathrm{C}$ com umidade relativa próxima de $100 \%$ e atmosfera gasosa de $5 \%$ de $\mathrm{CO}_{2}$ (Figura 3A-B). Após 4-5 dias em estufa, o meio das garrafas era desprezado, e novo meio colocado. Após esse período inicial, os meios das garrafas foram trocados de duas vezes por semana, ou de acordo com a necessidade das células.

As imagens das células incubadas foram visualizadas em microscópio de luz invertida (NIKON Eclipse-TS 100), sob objetivas de 4x, 10x, 20x e 40x e armazenadas através de sistema de captura (MTC Digital Color Camera). Ao atingir confluência de $90 \%$ as células eram repicadas. 

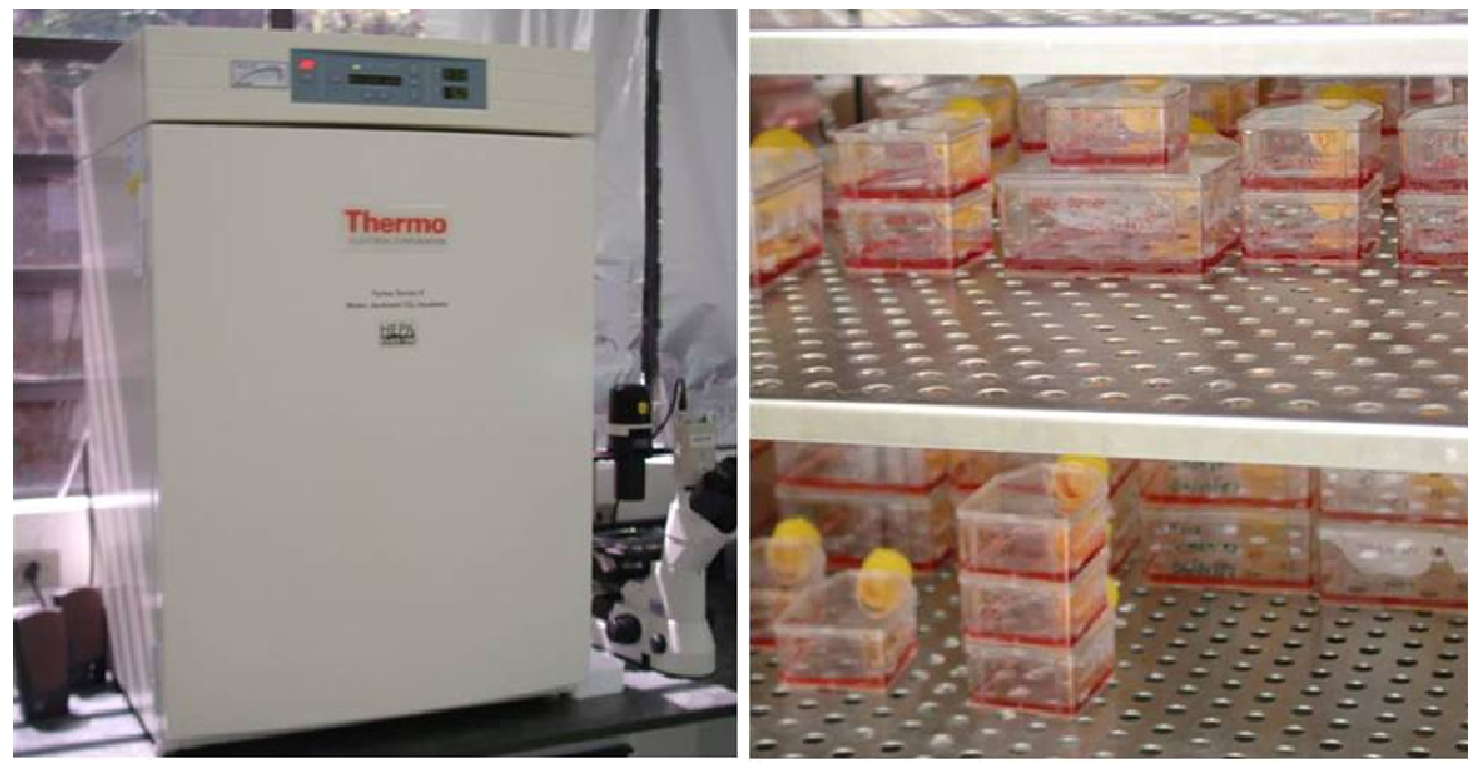

Figura 3 - Estufa umidificada com ambiente controlado a $37^{\circ} \mathrm{C}$ e $5 \%$ de CO2. A - Estufa Thermo Electron Corparation Forma Series II Water Jacketed $\mathrm{CO}_{2}$ Incubator HEPA Class 100. B - Cultivo de medula óssea em garrafas de $25 \mathrm{~cm}^{2}$ e $75 \mathrm{~cm}^{2}$

As garrafas em confluência de $85-90 \%$ foram repicadas rotineiramente, utilizando-se tripsina a $0,25 \%$. O repique era realizado desprezando-se o meio de cultivo das garrafas em descarte apropriado. Logo após era procedida duas lavagens com $5 \mathrm{ml}$ de PBS-L, com a finalidade de eliminar todo o meio de cultivo da garrafa.

Após a lavagem $1 \mathrm{ml}$ de Tripsina-EDTA a 0,25\% (Invitrogen) era adicionada as garrafas de $25 \mathrm{~cm}^{2}$ e no caso das garrafas de $75 \mathrm{~cm}^{2}$, eram adicionados $2 \mathrm{ml}$, então mesmas eram colocadas em estufa umidificada em ambiente controlado de $37^{\circ} \mathrm{C}$ e $5 \%$ de $\mathrm{CO} 2$ durante 5 minutos.

Após esse período de 5 minutos a tripsina era inativada com 0 próprio meio de cultivo, e o conteúdo da garrafa era depositado em tubos tipo falcon de $10 \mathrm{ml}$ com fundo cônico, sendo procedida centrifugação a 1100 RPM durante 7 minutos.

O sobrenadante resultante da centrifugação era desprezado, e o pellet era ressuspenso em $1 \mathrm{ml}$ do próprio meio de cultivo ( $a-M E M)$, 
retirada uma alíquota e quantificado o número de células em hematocitômetro. Novas garrafas de $25 \mathrm{~cm}^{2}$ eram então plaqueadas em densidade de $2 \times 10^{5}$ células. Com isto, uma curva de crescimento celular foi estabelecida a cada dois dias, a contagem supracitada.

As MSC da polpa dentária humana foram gentilmente cedidas pela Profa Dra Irina Kerkis do Laboratório de Genética do Instituto Butantan.

\subsection{VETORES RETROVIRAIS}

Para a introdução de genes exógenos foram transfectados nas células tronco da medula óssea de ovinos, vetores retrovirais derivados da estrutura do retrovírus MoMLV (Moloney Murine Leukemia Vírus).

$\mathrm{O}$ vetor retroviral utilizado, o pLNPoZ, possui o gene bacteriano LacZ ("Z") sob o controle da região UTR do Poliovírus ("Po"), o promotor viral do retrovírus LTR (L) que regula a expressão do gene neomicina fosfotransferase $(N)$.

\subsubsection{Cultivo de células de linhagens estabelecidas}

Os fibroblastos NIH3T3, células empacotadoras de vírus anfotrópicos PT67/LNPoZ foram gentilmente cedidas pelo Dr. Sang Won Han. Essas células foram cultivadas em meio DMEM suplementado com $2 \mathrm{mM}$ de glutamina, $200 \mathrm{U} / \mathrm{ml}$ de penicilina, $200 \mu \mathrm{g} / \mathrm{ml}$ de estreptomicina e $10 \%$ de soro fetal bovino (SFB). Esse meio suplementado é denominado DMEMc. 
As células foram mantidas em estufa a $37^{\circ} \mathrm{C}$, em atmosfera úmida contendo $5 \%$ de $\mathrm{CO}_{2}$.

O cultivo destas células foi realizado pela Professora Doutora Patrícia Cristina Baleeiro Beltrão Braga (USP), no Laboratório de Células Tronco (LCT) da FMVZ-USP.

4.6.2 Infecção de células-tronco da medula óssea de ovinos

Os experimentos de infecção das células-tronco seguiram um protocolo de cinco dias, mantendo-se um intervalo de 24 horas entre cada passo:

1 dia : Os clones de células empacotadoras anfotrópicas PT67/LNPoZ e as células tronco, passagem 2 ou 3, foram semeadas em placas de cultura de tecidos de $60 \mathrm{~mm}$ de diâmetro a uma densidade de $1 \times 10^{6}$ para as células produtoras de vírus e $5 \times 10^{5}$ para as células tronco, em $4 \mathrm{ml}$ de meio de cultivo supracitado.

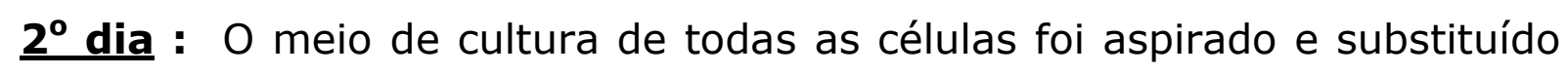
por meio novo.

30 dia : Infecção. O sobrenadante de cultura dos clones de células produtoras de vírus PT67 foram gentilmente homogeneizados, coletado e centrifugado a $10000 \mathrm{rpm}$ por 1 minuto a temperatura ambiente. 0 meio de cultura das células tronco foi novamente substituído por meio de cultura novo contendo $8 \mu \mathrm{g} / \mathrm{ml}$ de Polybrene. Um mililitro da suspensão viral foi usado para infectar cada placa de células-tronco.

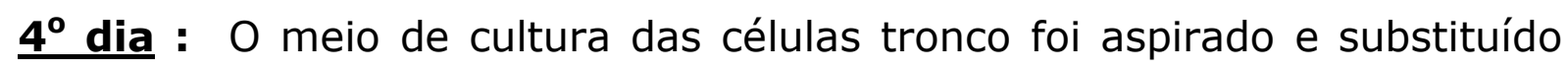
por meio novo.

Estas células não foram selecionados com geneticina, pois poderia interferir na terapia e essa população foi posteriormente implantada no 
centro do cabeça do fêmur através de técnica de descompressão central, a qual é explicada posteriormente.

4.6.3 Análise da expressão dos genes exógenos (LacZ) nas células tronco mesenquimais transduzidas previamente à transplante nos ovinos

Para verificar a expressão de $\beta$-galactosidase ( $\beta$-Gal) nas célulastronco da medula óssea de ovinos transduzidas com o vetor LNPoZ, $1 \mathrm{x}$ $10^{6}$ células foram semeadas em placas de $60 \mathrm{~mm}$ e, após 24 horas foram incubadas com uma solução de X-Gal. O protocolo de incubação com o XGal foi realizado como segue: o meio de cultura é removido e a solução de $0,5 \%$ de glutaraldeído é adicionada sobre as células para a fixação das mesmas. Segue-se uma incubação por 15 minutos à temperatura ambiente. A solução é removida e as células lavadas por três vezes com PBS em intervalos de 5 minutos cada. A solução de X-gal (X-gal $1 \mathrm{mg} / \mathrm{ml}$, $\mathrm{K}_{4} \mathrm{Fe}(\mathrm{CN})_{6} 5 \mathrm{mM}, \mathrm{K}_{3} \mathrm{Fe}(\mathrm{CN})_{6} 5 \mathrm{mM}$ e $\left.\mathrm{MgCl}_{2} 1 \mathrm{mM}\right)$ é adicionada às células que são incubadas a $37^{\circ} \mathrm{C}$ por $1-6$ horas. As células coradas foram visualizadas em microscópio de contraste de fase.

4.6.4 Preparação de células-tronco transduzidas para transplante nos animais

Células transduzidas em cultivo foram homogeneizadas e centrifugadas sob refrigeração a $1000 \mathrm{rpm}$ por 7 minutos. O precipitado 
celular foi ressuspendido com PBS e centrifugado a $1000 \mathrm{rpm}$ por 7 minutos. Essa lavagem com PBS foi realizada duas vezes com o intuito de remover traços de SFB. Após a contagem das células, a quantidade estipulada para o transplante foi ressuspendida em soro fisiológico para ser inoculada nos animais.

\subsection{TÉCNICA DE DESCOMPRESSÃO CENTRAL EM OVINO}

Tanto para indução da osteonecrose, quanto para a realização da terapia celular, os animais foram submetidos a protocolo cirúrgico de descompressão central, seguido da injeção de etanol absoluto através de broca canulada diretamente na cabeça do fêmur.

A pele dos animais é incisada como de rotina com lâmina de bisturi no 14, divulsionados tecidos moles e a fáscia muscular foi incisada para dar acesso aos músculos.

A musculatura é incisada até a região proximal ao trocânter maior. Um fio de Kirschner de $1 \mathrm{~mm}$ foi introduzido desde o trocânter maior até aproximadamente $3 \mathrm{~mm}$ de distância da cartilagem articular da articulação coxofemoral.

Quando a posição do fio de Kirschnner foi constatada radiograficamente através de incidência ventro-dorsal, uma broca canulada de 3,2 mm será introduzida até a região supracitada, onde então se retira o fio guia e injetam-se foram $8 \mathrm{ml}$ de etanol absoluto.

Ao final do procedimento a broca foi retirada, e o orifício criado foi preenchido com cera para osso (Johnson \& Johnson), a musculatura foi aproximada com sutura simples contínua com Vycril ${ }^{\circledR}$ 2-0 e pele com suturas simples separada com Nylon 2-0. 


\subsection{EXAME RADIOGRÁFICO}

Todos os procedimentos radiográficos utilizados neste experimento foram realizados no setor de radiologia Universidade Fundação de Ensino Octávio Bastos (UNIFEOB).

Para realização das imagens radiográficas utilizamos a projeção ventro-dorsal, com chassi Konex 30x40, filme AGFA ${ }^{\circledR}$. O aparelho utilizado era da marca Emic ${ }^{\circledR}$ com ampola Toshiba, $500 \mathrm{~mA}$ e $150 \mathrm{Kv}$. A técnica utilizada foram $300 \mathrm{~mA}, 80 \mathrm{Kv}$ a 0,08s.

\subsection{ANÁLISE POR MICROSCOPIA DE LUZ}

Os animais foram eutanasiados com overdose de tiopental sódico a 2,5\%. A cabeça do fêmur dos animais experimentais foi dissecada, coletada e imersa durante 48 horas em solução de formalina a $10 \%$.

A cabeça do fêmur foi seccionada no colo femoral e em 4 fatias paralelas ao centro da cabeça do fêmur. As peças foram incluídas em metilmetacrilato (MMA) conforme protocolo a seguir: 


\section{Protocolo para inclusão em MMA}

1 - Álcool 70\%--------------2 dias $-4^{\circ} \mathrm{C}$

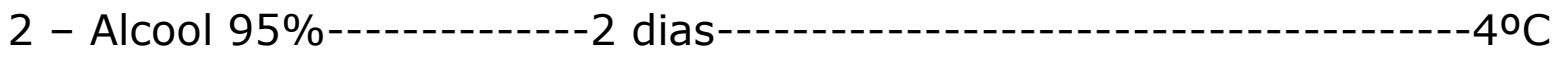

3 - Alcool 100\%----1 dia---

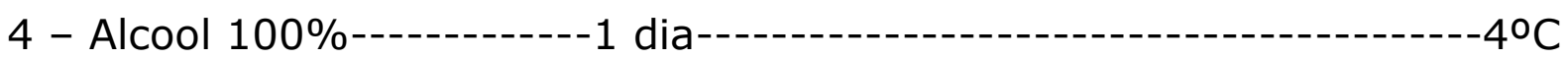

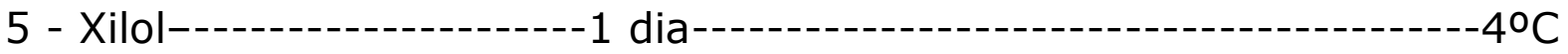

6-Solução I --------2 dias ---

Solução I: Metil metacrilato $=75 \mathrm{ml}$

Dibutril fostalato $=25 \mathrm{ml}$

7-Solução II----------------2 dias

Solução II: Metil metacrilato $=75 \mathrm{ml}$

Dibutril fostalato $=25 \mathrm{ml}$

Peróxido de benzoila $=1 \mathrm{gr}$

8-Solução III--------------2 dias -39 a $40^{\circ} \mathrm{C}$

Solução III: Metil metacrilato $=75 \mathrm{ml}$

Dibutril fostalato $=25 \mathrm{ml}$

Peróxido de benzoila $=2.5 \mathrm{gr}$

Alternativamente ao método de inclusão em MMA realizamos a descalcificação em ácido fórmico a $10 \%$ em parte do material coletado para processamento histológico. De semana em semana, as peças eram testadas com a perfuração de uma agulha, quando a agulha atravessasse o material sem oferecer resistência os ossos eram considerados descalcificados. Logo em seguida o material era processado seguindo o protocolo histológico de rotina para coloração em hematoxilina e eosina:

\section{Coloração em Hematoxilina e Eosina}

- Xilol I - 10 minutos

- Xilol II - 10 minutos 
- Álcool $100 \%$ I - 3 minutos

- Álcool $100 \%$ II - 3 minutos

- Álcool 95 \% - 3 minutos

- Álcool 70 \% - 3 minutos

- Álcool 50 \% - 3 minutos

- Lavagem em água corrente - 5 minutos

- Hematoxilina de Harris - 3 minutos

- Lavagem em água corrente - 5 minutos

- Eosina - 30 segundos

- Lavagem em água corrente - 5 minutos

Posteriormente, realizou-se a diafanização através do processo inverso, desde álcool até o xilol, utilizando-se as mesmas concentrações e tempos. A montagem das lâminas foi realizada com resina Citoseal. Colorações em hematoxilina-eosina e tricomio de masson foram feitas para analisar a estrutura microscópica. 


\section{RESULTADOS}

Os resultados serão trabalhados em tópicos, em virtude das diferentes vertentes utilizadas nesse trabalho.

\subsection{CULTIVO DAS CÉLULAS-TRONCO MESENQUIMAIS DA MEDULA ÓSSEA DE OVINOS}

Utilizamos o protocolo de isolamento de células mononucleares descrito no material e métodos, e em alguns casos foi colocada a medula óssea total dos ovinos em cultivo, devido ao insucesso na separação das células mononucleares em algumas coletas. Os cultivos celulares obtidos através de separação com solução para separação por gradiente de densidade Ficoll (Histopaque ${ }^{\circledR}$ ) obtiveram maior sucesso do que os cultivos de medula óssea total.

O pellet formado, na separação das células mononucleares da medula óssea com Ficoll (Histopaque ${ }^{\circledR}$ ), de tamanho reduzido, com aspecto semelhante à uma névoa, de tamanho aproximado a um anel. As coletas de medula de animais mais jovens, com menos de 1 ano de idade, coincidiram com a formação de pellets mais evidentes (Figura 4A).

Foram testados nos cultivos de células-tronco de medula óssea de ovinos os meios: alpha minimum essential medium ( $\alpha$-MEM) (SIGMAALDRICH), DMEM-Low Glucose (SIGMA-ALDRICH) e DMEM High Glucose (SIGMA-ALDRICH). Nossos cultivos celulares apresentaram melhores resultados com o meio a-MEM (SIGMA-ALDRICH). 
As células-tronco mesenquimais podem ser diretamente isoladas dos aspirados de medula por causa da sua habilidade de adesão à superfície da garrafa de cultura. Após 3-4 dias de cultivo em estufa controlada ( $37^{\circ}$ e $5 \%$ de umidade) as células que não aderiram ao fundo da garrafa foram removidas através da aspiração do meio de cultura, restando aderidas as células-tronco mesenquimais. As garrafas foram examinadas em microscópio óptico invertido, onde foram observadas as primeiras células de aspecto fusiforme aderidas ao fundo (Figura 4B).

As células-tronco mesenquimais da medula óssea de ovinos não apresentam homogeneidade de forma quando em cultivo primário. Foram notadas células de formas variadas, de acordo como aderiam ao fundo da garrafa de cultivo (Figura 4C).

As células cultivadas proliferaram até atingirem confluência de 8090\% (Figura 4D), quando foram repicadas com Tripsina-EDTA a 0,25\% (Invitrogen, Cat. No 25200-114), e quantificadas em câmara de neubaer. Logo após as mesmas eram colocadas novamente em cultivo na concentração de $2 \times 10^{5}$ em garrafas de $25 \mathrm{~cm}^{2}$. 


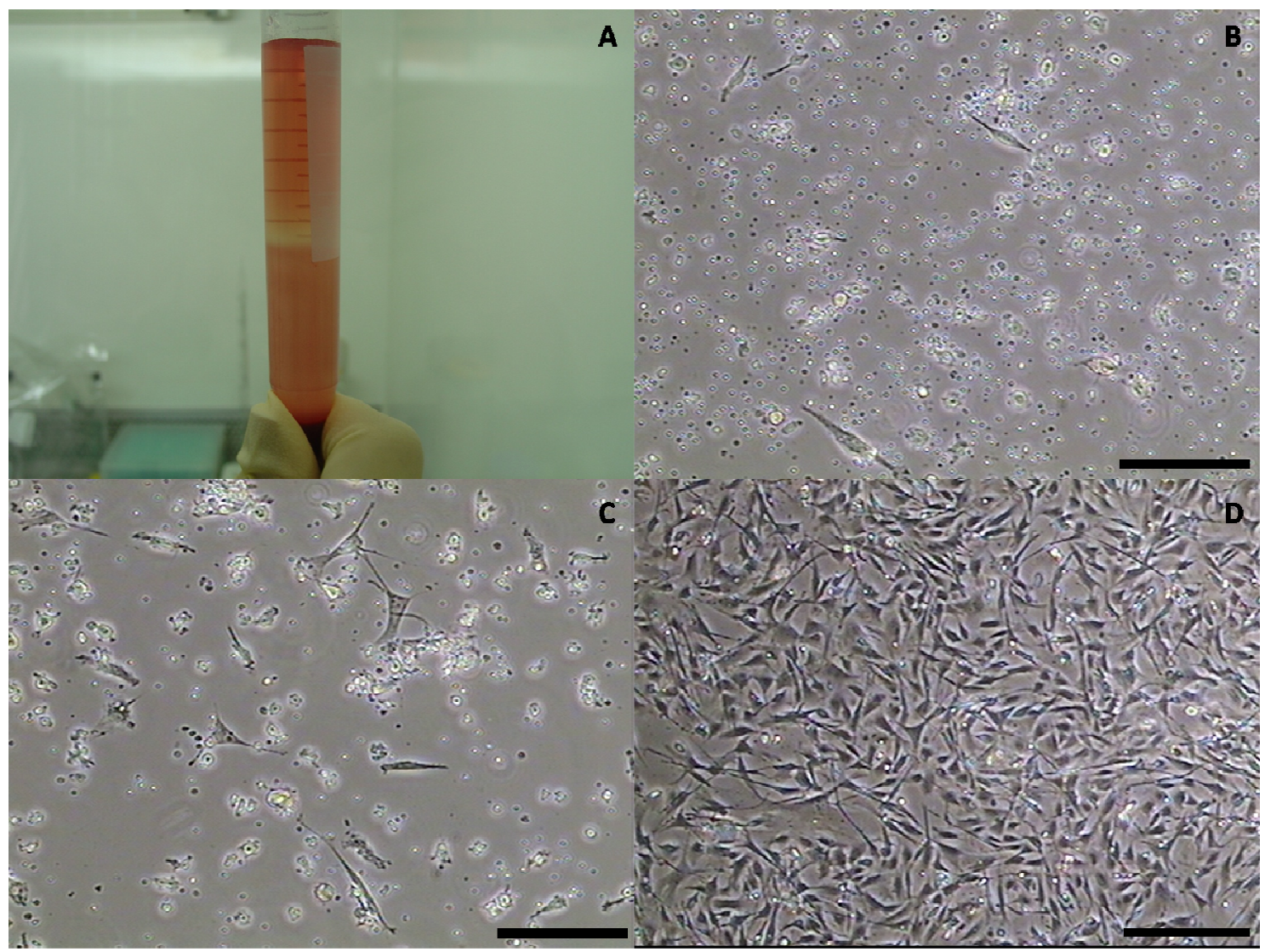

Figura 4 - Fotografia e fotomicrografias da separação e cultivo de células-tronco da medula óssea de ovinos. A - Visualização do pellet formado separação com solução para separação por gradiente de densidade Ficoll (Histopaque ${ }^{\circledR}$ ). B Células da medula óssea de ovinos de formato fusiforme aderidas ao fundo da garrafa após quatro dias de cultivo. C - Heterogeneidade das formas das células de medula óssea de ovinos em cinco dias de cultivo. D - Observamos as celulas da medula óssea de ovino em confluência de $85 \%$ após 3 semanas de cultivo. (B) Barra de $100 \mu \mathrm{m}$ e (C,D) barras de $250 \mu \mathrm{m}$.

Duas garrafas foram utilizadas com a finalidade de produzir uma curva de crescimento destas células em cultivo. Foram utilizadas duas marcas diferentes de soro fetal bovino ( $X$ e $Y$ ) para suplementação dos meios de cultivo (a-MEM) de cada garrafa. Estas garrafas foram repicadas dia sim, dia não, durante 22 dias, conforme demonstrado no Gráfico 1. 


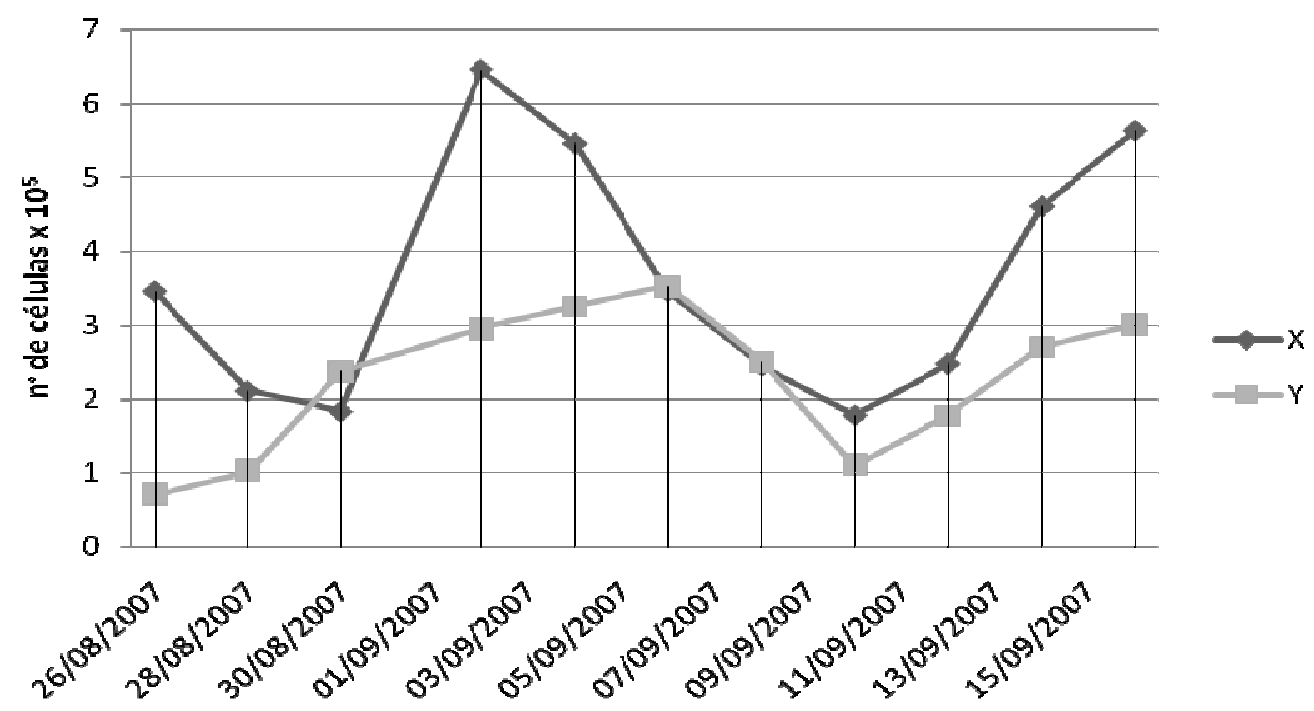

Gráfico 1- Curva de crescimento das Células-Tronco Mesenquimais da Medula Óssea de Ovinos

Aparentemente esta curva sugere um crescimento celular em ciclos. A marca de soro fetal (SF) Hyclone apresentou picos de crescimento maiores quando comparados a marca de SF Cripion, embora o soro fetal Cripion demonstre certa estabilidade quando comparado ao SF Hyclone. A alternância de manipuladores das células também pode ter sido um fator para a formação desta curva de crescimento, muito embora o crescimento e declínio apresentando sugiram um crescimento e declínio celular uniforme.

5.2 REALIZAÇÃO DA TÉCNICA DE DESCOMPRESSÃO CENTRAL EM OVINOS

A técnica cirúrgica foi realizada com o auxílio de imagens radiográficas realizadas no momento do ato cirúrgico, dispensando a necessidade da utilização de fluoroscópio para a realização do procedimento. 
Os procedimentos cirúrgicos foram realizados na sala de radiologia da Universidade Fundação de Ensino Octávio Bastos (UNIFEOB), dessa forma, a realização do procedimento era efetivado com maior tranqüilidade, evitando a necessidade de transporte dos animais do centro cirúrgico até a sala de $\mathrm{Rx}$.

Para realização da técnica cirúrgica acessamos o trocânter maior através da incisão da pele com lâmina de bisturi 14 e da divulsão de tecido subcutâneo. O músculo glúteo superficial foi incisado na direção as suas fibras musculares, assim como o músculo bíceps femoral, afastandose com o auxílio de um afastador auto-estático de Weitlaner (Figura 5A).

Confirmada a visualização do trocânter maior, foi introduzido um fio de Kirschnner do trocânter maior até o centro da cabeça femoral (Figuras 4B e 5B). Para que o trocânter maior ficasse alinhado corretamente com a cabeça do fêmur dos animais, era necessário que um auxiliar esticasse e torcesse o membro do animal medialmente, dessa forma o fio pode ser introduzido com facilidade até o centro da cabeça do fêmur. Confirmada a posição radiográfica correta do fio, a broca canulada era introduzida até o centro da cabeça do fêmur (Figura 4C e 5C), o fio era então retirado do local, e nova imagem radiográfica era produzida para aferir a correta localização da broca no centro da cabeça do fêmur (Figura 4D). 


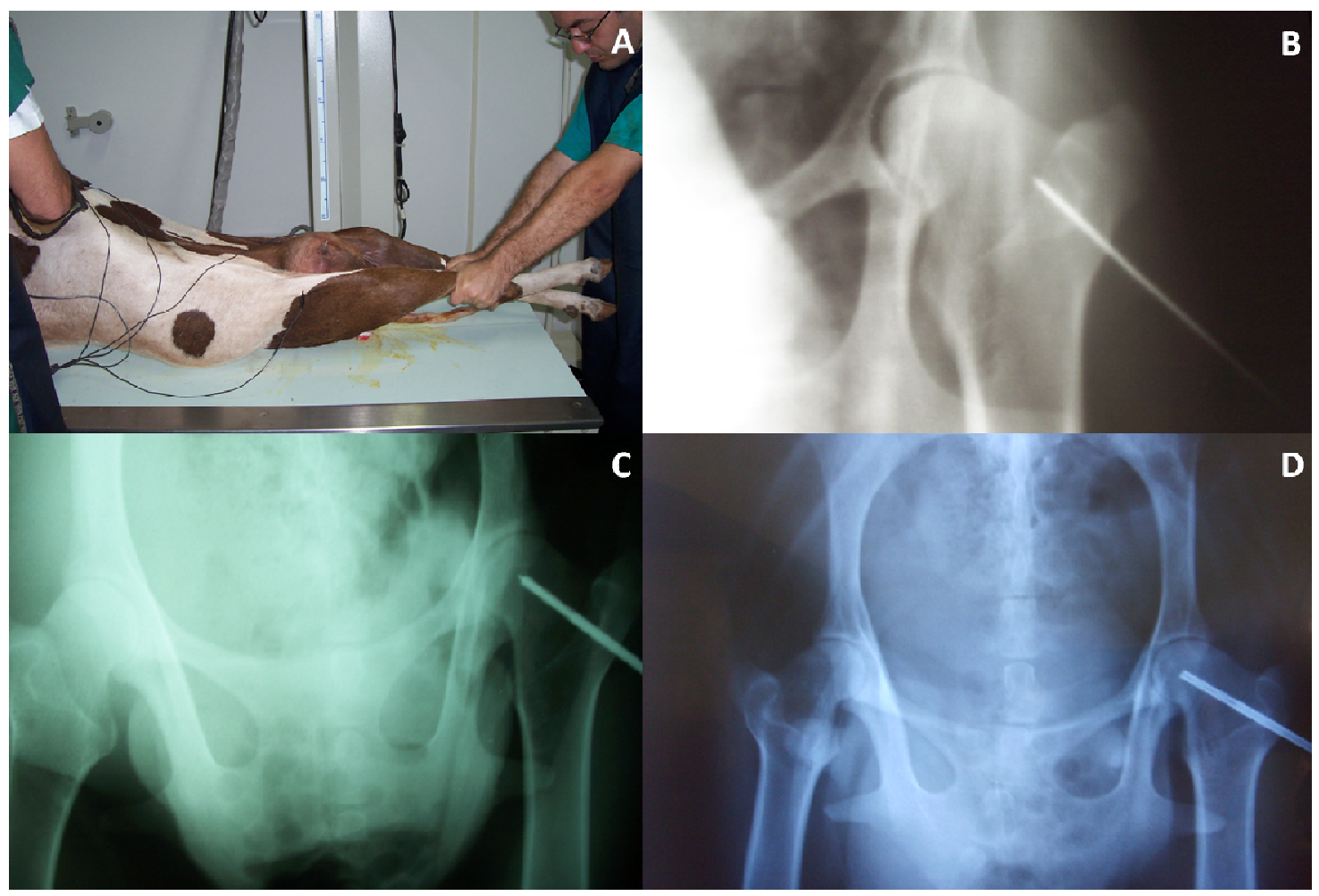

Figura 4 - Radiografias trans-operatórias em ovinos para indução da osteonecrose da cabeça do fêmur. A - Posicionamento do animal para projeção ventro-dorsal. B - Direcionamento correto do fio de Kirschnner de $1 \mathrm{~mm}$. C - Broca canulada adentrando no centro da cabeça do fêmur, tendo como guia o fio de Kirschnner. D - Broca canulada no local adequado para a realização da indução da ONCF

Com a broca canulada corretamente e posicionada no centro da cabeça do fêmur, o etanol absoluto era então injetado, em velocidade aproximada de $1 \mathrm{ml}$ por minuto, em um volume total de $8 \mathrm{ml}$ (Figura 5D). Ao final do procedimento a broca foi retirada, e o orifício criado foi preenchido com cera para osso (Johnson \& Johnson), a musculatura foi aproximada com sutura simples contínua com Vycril ${ }^{\circledR}$ 2-0 e pele com suturas simples separada com Nylon 2-0. 


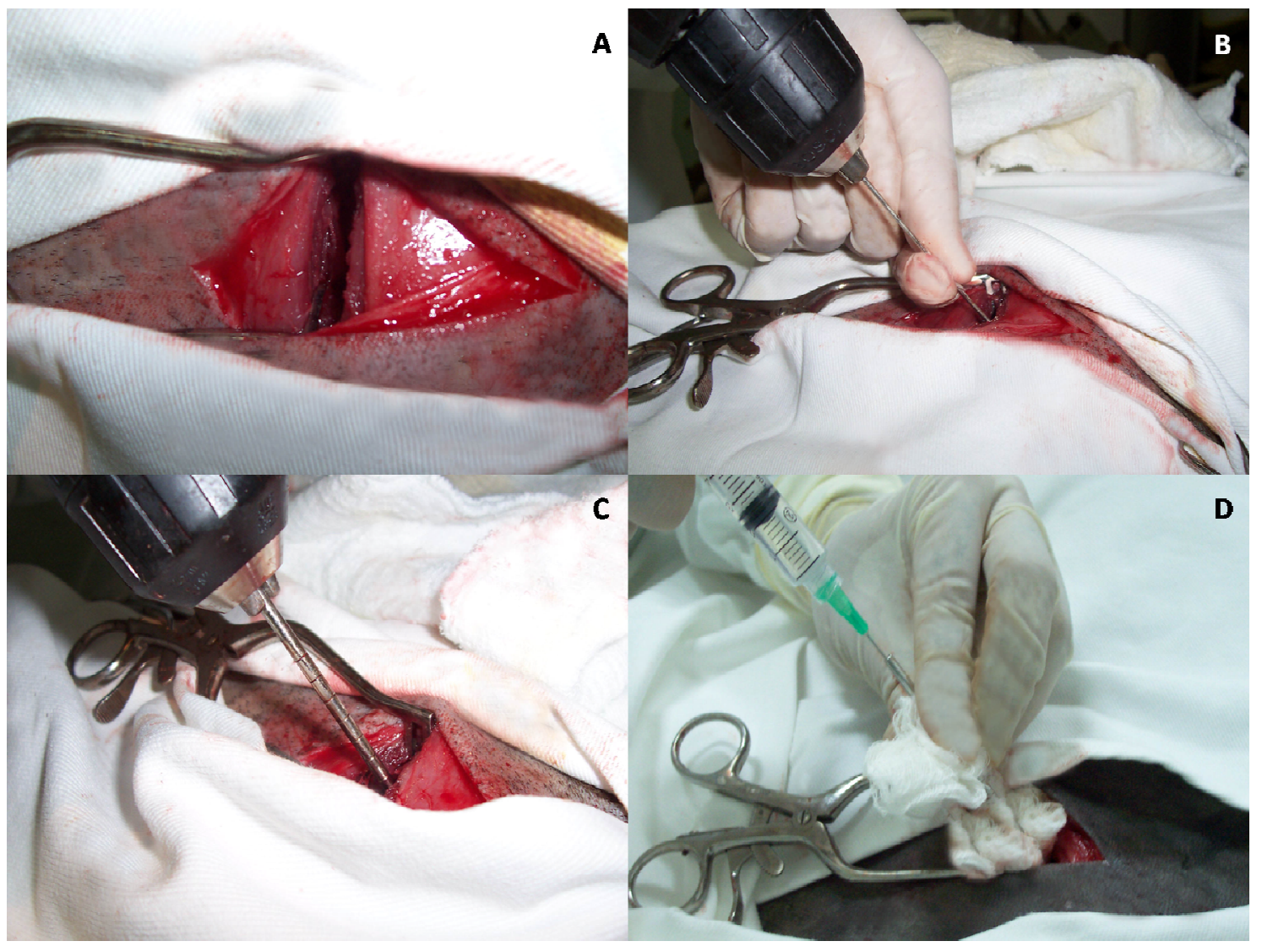

Figura 5 - Técnica de Descompressão central da cabeça do fêmur com injeção de etanol absoluto. A - Pele e musculatura afastadas com a utilização de afastador auto-estático de Weitlaner. B - Passagem do fio de Kirschnner de $1 \mathrm{~mm}$ do trocânter maior até o centro da cabeça do fêmur. C - Introdução da broca canulada. D - Injeção de etanol absoluto no centro da cabeça do fêmur

Os animais submetidos à descompressão central com células da polpa dentária humana receberam $1 \times 10^{7}$ células, e os animais que receberam células da medula óssea de ovinos transduzidas receberam $1 \times 10^{6}$ células.

Os animais foram eutanasiados em 6 e 10 semanas e separados de acordo com o tratamento recebido. Foram coletadas as cabeças de fêmur direito (controle) e esquerdo (experimental) dos animais eutanasiados para processamento histológico e confirmação da necrose óssea (Quadro 1). 


\begin{tabular}{|c|c|c|c|}
\hline $\begin{array}{l}\text { IDENTIFICAÇÃO } \\
\text { DOS ANIMAIS }\end{array}$ & TRATAMENTO & $\begin{array}{c}\text { EUTANÁSIA COM } 6 \\
\text { SEMANAS }\end{array}$ & $\begin{array}{c}\text { EUTANÁSIA COM } 10 \\
\text { SEMANAS }\end{array}$ \\
\hline 33 & Descompressão & $x$ & \\
\hline 24 & Descompressão & $x$ & \\
\hline 248 & $\begin{array}{l}\text { Células da Polpa } \\
\text { dentária Humana }\end{array}$ & & $x$ \\
\hline 121 & $\begin{array}{l}\text { Células da Polpa } \\
\text { dentária Humana }\end{array}$ & & $x$ \\
\hline 14 & $\begin{array}{l}\text { Células da medula } \\
\text { Óssea de Ovino }\end{array}$ & & $x$ \\
\hline 27 & $\begin{array}{l}\text { Células da medula } \\
\text { Óssea de Ovino }\end{array}$ & & $x$ \\
\hline 4 & Descompressão & & $x$ \\
\hline 13 & Descompressão & & $x$ \\
\hline
\end{tabular}

Quadro 1 - Tratamentos com células-tronco mesenquimais de duas fontes e eutanásias de ovinos com osteonecrose da cabeça do fêmur induzida

Algumas alterações macroscópicas foram observadas em exemplares da cabeça de fêmur de alguns carneiros, quando comparados os lados direito (controle) e esquerdo (experimental). No carneiro de número 004, injetado com células-tronco de polpa de dente, passadas 10 semanas da realização da eutanásia, foi possível observar lesões hemorrágicas e uma área circular mais clara na cabeça de fêmur esquerda com relação ao restante da cabeça do fêmur, semelhante a um infarto ósseo, comumente encontrado nas cabeças de fêmur humanas com ONCF (Figura 6). 


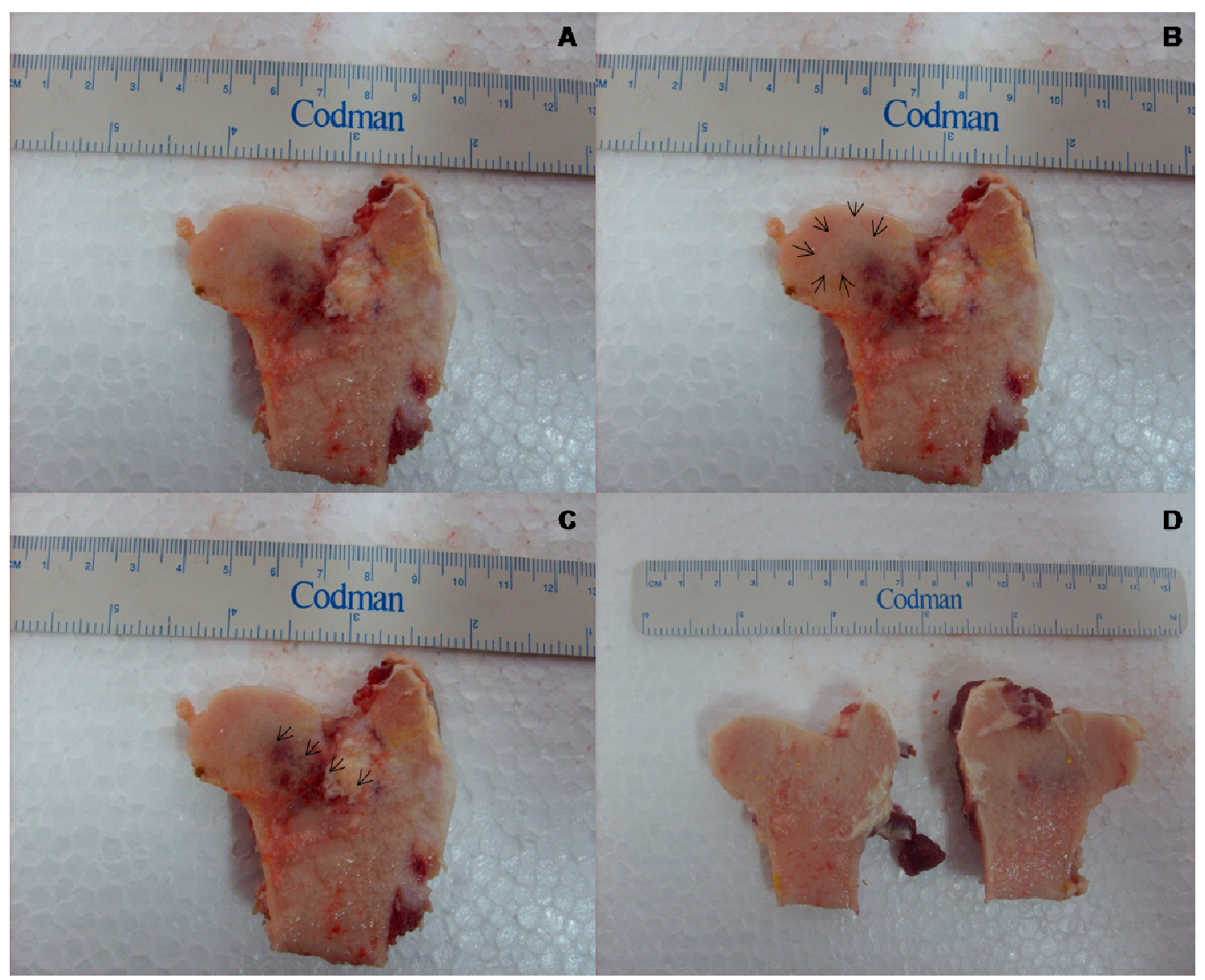

Figura 6 - Aspecto macroscópico de cabeça e colo femorais de ovino submetido à indução de osteonecrose da cabeça do fêmur e terapia celular com célulastronco da polpa dentária humana. A - Aspecto da cabeça do fêmur de carneiro submetido à indução de ONCF. B - As setas delimitam a área de infarto óssea visível em (A). C - Setas apontam a passagem da broca canulada do trocânter maior ao centro da cabeça do fêmur. D - Cabeça do fêmur do membro contralateral do mesmo animal 
5.3 ANÁLISE DA EXPRESSÃO DO GENE REPÓRTER LaCZ NAS CÉLULASTRONCO MESENQUIMAIS DA MEDULA ÓSSEA DE OVINO

A transdução das células-tronco foi realizada de acordo com o protocolo no item $X$. As células NIH3T3 foram utilizadas como controle positivo de infecção. As células de medula óssea e as células NIH3T3 foram eficientemente transduzidas e o gene repórter foi expresso, de acordo com os resultados observados nas figuras 7 e 8 .

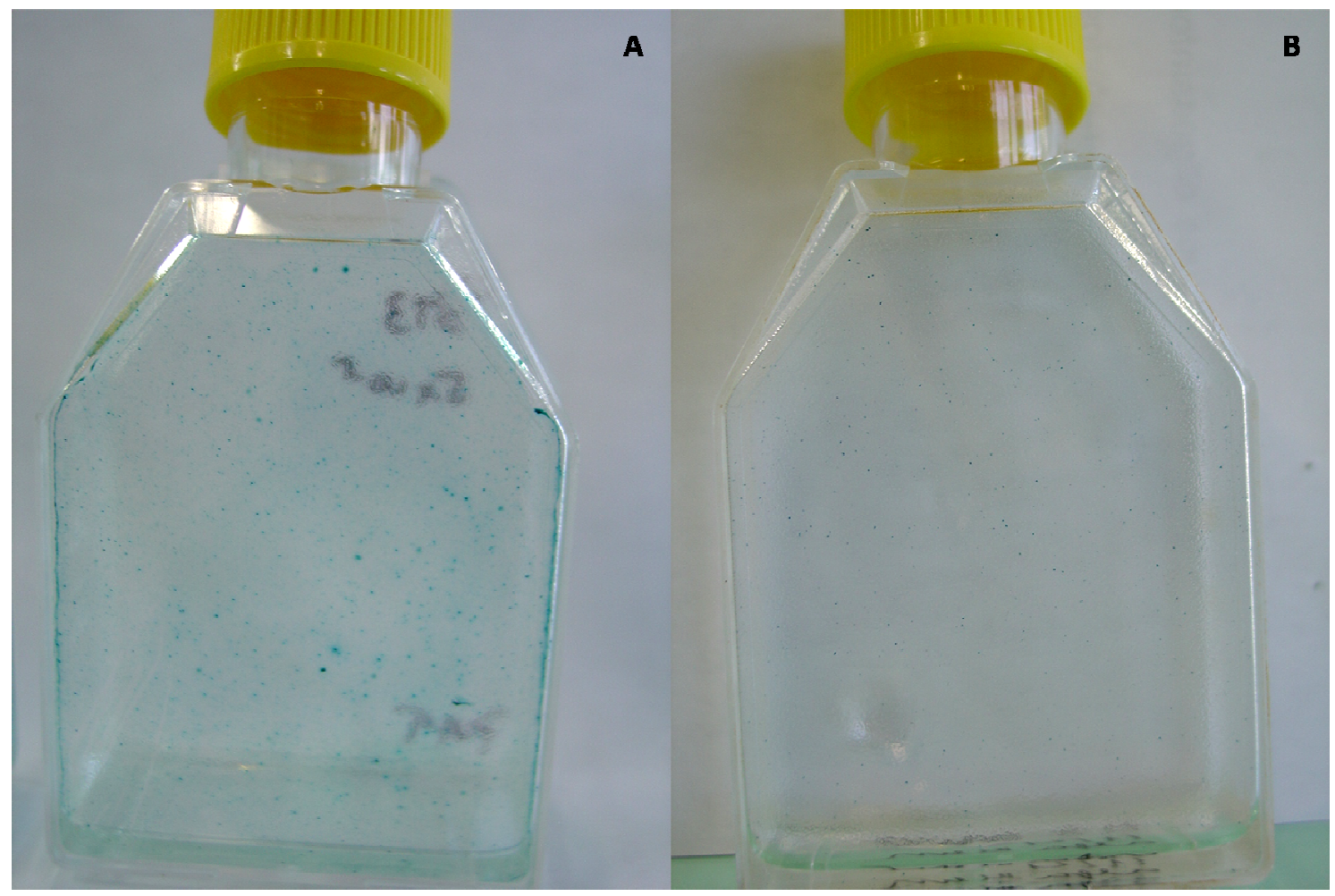

Figura 7 - Fixação das células com X-Gal demonstrando a expressão do gene repórter LacZ nas NIH3T3 e em células-tronco da medula óssea de ovinos. A Expressão da $\beta$-Gal pelas células NIH3T3 coradas com X-Gal. B - Expressão da $\beta$-Gal pelas células-tronco da medula óssea de ovinos 


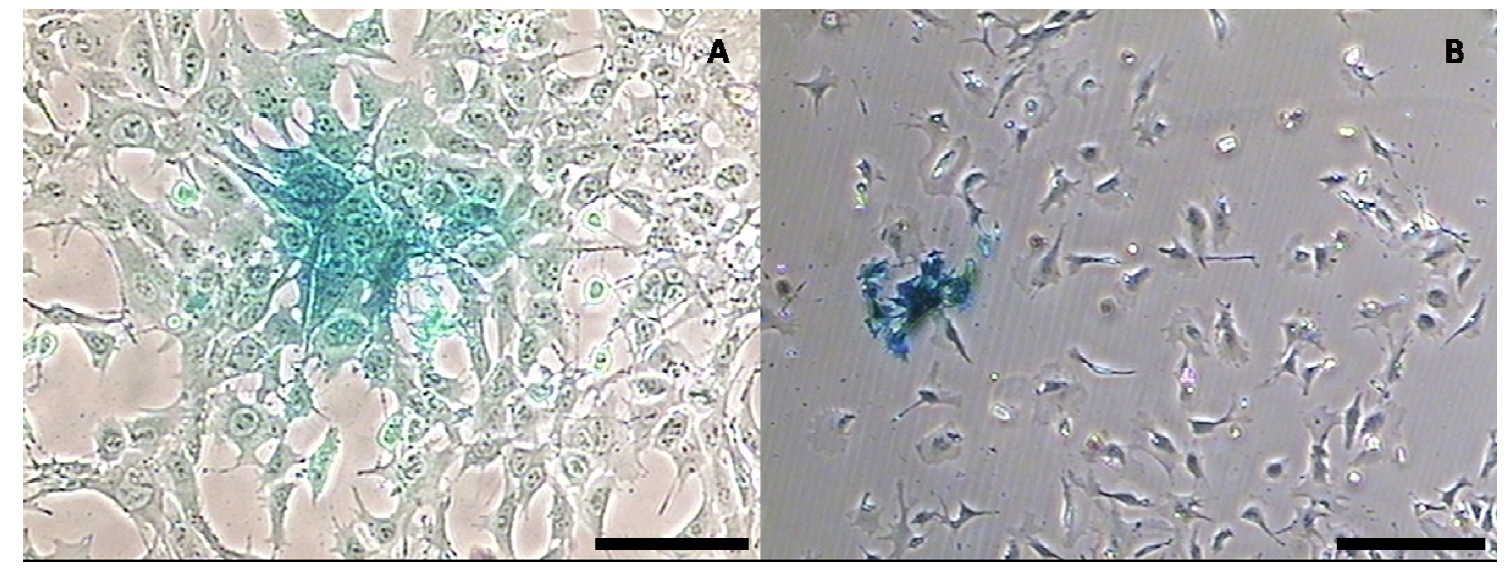

Figura 8 - Expressão do gene repórter LacZ nas células NIH3T3 e nas células-tronco da medula óssea em ovinos. A - Expressão do gene repórter em células NIH3T3. C - Expressão do gene repórter em células-tronco da medula óssea de ovinos. Em (A) barra de $100 \mu \mathrm{m}$, em (B) barra de $250 \mu \mathrm{m}$

5.4 ANÁLISE DA EXPRESSÃO DO GENE REPÓRTER LacZ NAS CÉLULASTRONCO MESENQUIMAIS DA MEDULA ÓSSEA IN VIVO

Foram injetadas $1 \times 10^{6}$ células-tronco da medula óssea de ovino transduzidas com o gene repórter LacZ, em $1 \mathrm{ml}$ de solução fisiológica, no centro da cabeça do fêmur dos animais 14 e 27. As amostras da cabeça do fêmur foram coletadas após 4 semanas pós-transplante e 10 semanas pós-indução, e então coletadas na eutanásia, as quais foram processsadas seguindo o mesmo protocolo para análise da expressão das células mesenquimais da medula óssea in vitro. Foram utilizadas amostras da cabeça do fêmur controle e experimental. As células de medula óssea injetadas no centro da cabeça do fêmur proliferaram e expressaram a $\beta$ galactosidase em contato com o X-Gal, confirmando o sucesso do transplante de células-tronco da medula óssea para o tratamento da ONCF (Figura 9). 


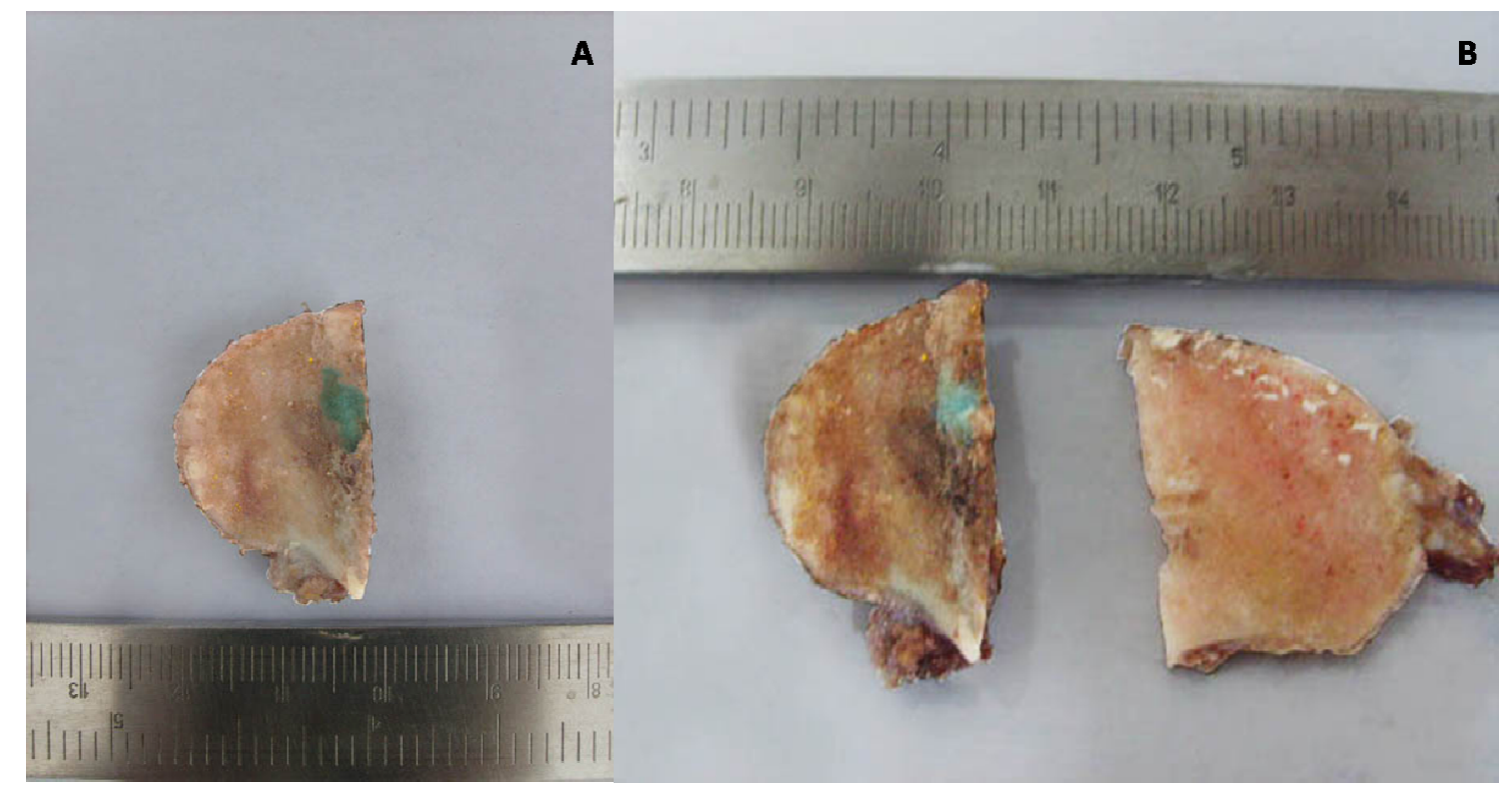

Figura 9 - Expressão do gene repórter LacZ na cabeça do fêmur de ovinos. A - Fatia da cabeça do fêmur esquerda de ovino expressando o gene repórter LacZ. B Cabeça do fêmur esquerda (experimental) e direita (controle) de ovino

\subsection{ANÁLISE MICROSCÓPICA}

O protocolo de inclusão em resina foi seguido conforme descrito no material em métodos. Não foi possível a obtenção de cortes do material incluído em MMA, devido a problemas na inclusão do material. O processo de secagem da resina não foi eficiente, resultando na obtenção de uma resina mais mole que o osso, o que impossibilitou o corte do material.

Como alternativa ao processo de inclusão em MMA seguimos a descalcificação óssea com ácido fórmico a $10 \%$ de espécimes de cabeça do fêmur de dois animais experimentais e um animal controle. Foram feitas lâminas para análise histológica de um animal injetado com MSC de 
polpa dentária humana (121e), um submetido à descompressão central sem a injeção de MSC (4e), e uma ovelha para controle (13d).

A porção trabecular da cabeça do fêmur da ovelha 4e (esquerda experimental) estava preenchida por medula óssea viva, rica em células mesenquimais e osteoblastos, típica de animais jovens em desenvolvimento ou em regiões de reparação de injúrias (Figura 10A). Aparente diminuição do espaço composto por osso compacto e desorganização das trabéculas ósseas foi outro achado relevante. Aumentos maiores dessa mesma região permitiram a visualização de células precursoras da osteogênese oriundas da própria medula, semelhantes a células mesenquimais, diferenciando-se em osteoblastos e formando novo tecido ósseo (Figura 10B).

A avaliação histológica da cabeça do fêmur do animal $121 \mathrm{e}$ permitiu a visualização de resquícios de medula viva no osso trabecular próxima a cartilagem (Figura 10D), muito embora em quantidade menor da encontrada no animal 4e. O osso trabecular estava mais organizado do que o encontrado no animal 4e, e com aparência semelhante ao animal 13d (figura 10C). 


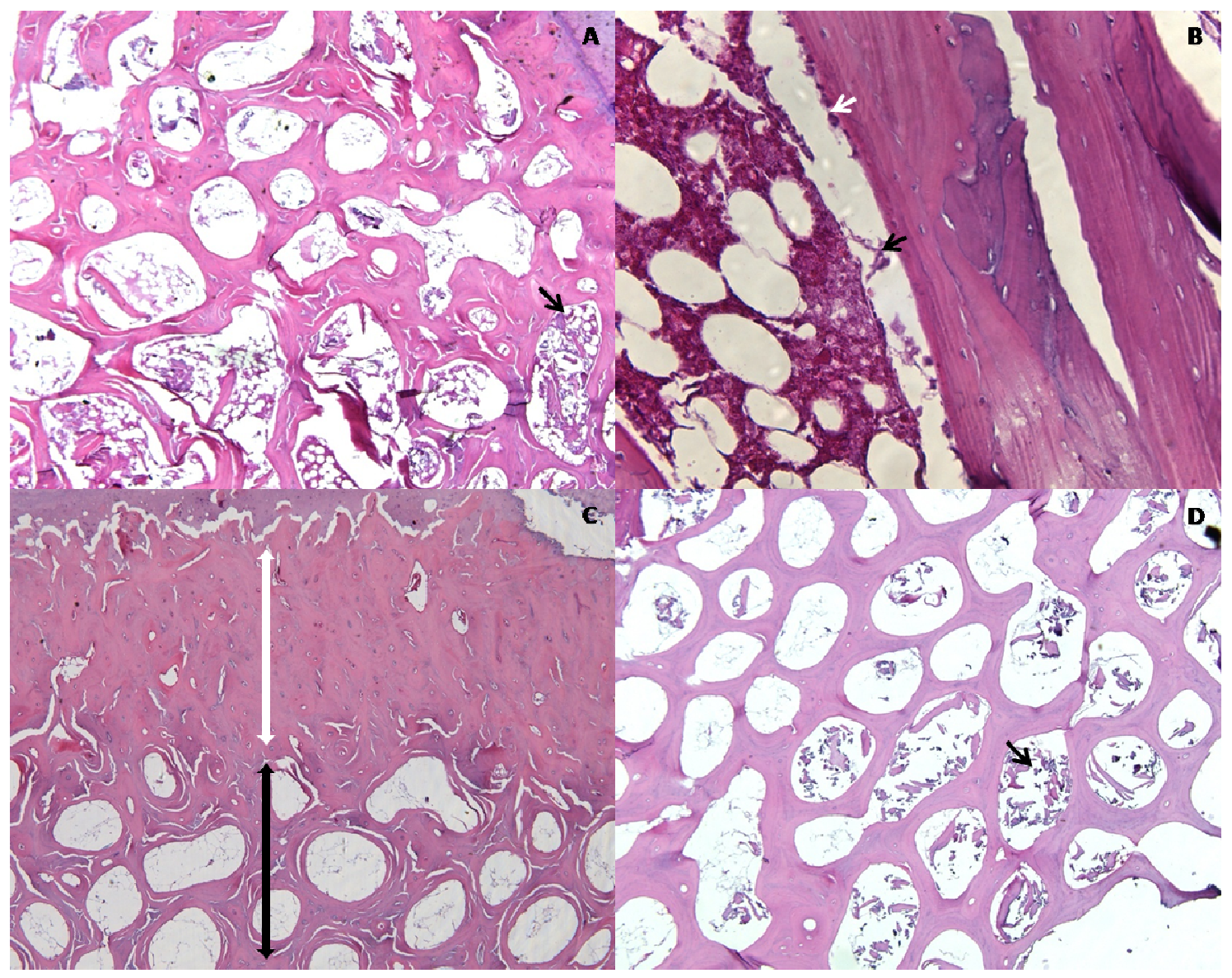

Figura 10 - Fotomicrografias da cabeça do fêmur de ovelhas submetidas à indução de osteonecrose da cabeça do fêmur por etanol e transplante heterólogo de células-tronco mesenquimais de diferentes fontes. A - Seta indicando presença de medula viva no interior da trabécula óssea. B - Aumento da região evidenciada em (A), seta preta aponta para célula de origem mesenquimal, seta branca aponta para osteoblastos. C - Seta branca delimitando a região de osso lamelar compacto e seta preta a região de osso trabecular em animal controle. D - Osso trabecular, seta aponta resquícios de medula óssea viva. Objetivas de 4x ( $A, C$ e D) e de 40X (B) 


\section{DISCUSSÃO}

O ovino apresenta características únicas que fazem deste animal o modelo experimental de escolha para tentativas clínicas na ortopedia. A anatomia da articulação coxofemoral destes animais é anatomicamente semelhante à humana, o que permite a avaliação de procedimentos cirúrgicos utilizados em humanos (KIRKER-HEAD et al., 1998).

A ONCF é uma patologia degenerativa e progressiva que culmina com o colapso da cabeça do fêmur e a necessidade de substituição da mesma através de próteses. Desde que Hernigou et al. (1999) relataram a diminuição da atividade e número de células-tronco mesenquimais nos sítios de ONCF, a terapia celular com células-tronco mesenquimais parece ser a alternativa mais viável para o tratamento conservativo dessa doença.

A descompressão central vem sendo usada como tratamento para a ONCF há 3 décadas, muito embora apresentando resultados controversos (FICAT, 1985). Embora esta técnica seja extensivamente utilizada na medicina humana, o mesmo não se aplica a medicina veterinária, o que pode estar relacionado ao alto custo de aquisição de um fluoroscópio. Neste experimento realizamos a técnica de descompressão central com $\circ$ auxílio de imagens radiográficas trans-operatórias, dispensando o uso da fluoroscopia, e diminuindo os custos relativos à realização desta técnica, abrindo as portas para sua utilização em medicina veterinária.

Gangji et al. (2002) preconizaram o uso da técnica de descompressão central associada ao transplante de células-tronco mononucleares da medula óssea no tratamento da ONCF. Após cinco anos de acompanhamento clínico dos 10 pacientes submetidos à técnica experimental, apenas 1 teve necessidade de nova cirurgia para 
substituição da cabeça do fêmur, enquanto que dos 8 pacientes submetidos a descompressão central, em 4 houve a necessidade da cirurgia para colocação de prótese (GANGJI et al., 2007). Muito embora não possa afirmar de fato o quanto estas células participaram de fato na recuperação deste paciente, devido a dados histológicos de biópsia, bem como de marcadores que possam afirmar a viabilidade destas células no tecido ósseo após transplante.

Apesar de haverem dados clínicos relevantes acerca da terapia celular na ONCF (GANGJI et al., 2002; GANGJI et al., 2004; GANGJI et al., 2005; GANGJI et al. 2007) não se sabe quanto de fato estas células ajudam, ou participam no processo de neoformação óssea e quantas destas células sobreviveram após o transplante e se proliferaram de fato no centro da cabeça do fêmur, fato ressaltado por Hassan e El-Shememy, (2004). Neste experimento injetamos células-tronco mesenquimais de ovino transduzidas com o gene repórter LacZ, e obtivemos sucesso na expressão da $\beta$-galactosidase através da fixação com $0 \quad$ X-Gal macroscopicamente, o que denota uma proliferação celular 4 semanas após a realização do transplante.

$\mathrm{O}$ isolamento e cultivo das células-tronco mesenquimais da medula óssea foi referendado por Rhodes e Srivastava (2004) que avaliaram a heterogeneidade e proliferação destas células. Os autores utilizaram para isolamento das células o critério de aderência ao plástico e sucessivas trocas de meio eliminando as células mononucleares, hematopoiéticas e debris. O mesmo critério de separação foi utilizado nesse experimento, aumentando a homogeneidade do cultivo com as trocas de meios.

As células-tronco mesenquimais da medula óssea de ovinos foi isolada e caracterizada por Mrugala et al. (2008). O protocolo utilizado para o isolamento e cultivo das células-tronco mesenquimais foi o mesmo utilizado neste experimento com sucesso.

As células-tronco mesenquimais apresentam grandes possibilidades terapêuticas para utilização na ortopedia, devido à facilidade de obtenção, 
isolamento e cultivo das mesmas, embora ainda haja a necessidade de estudos específicos para sua utilização em tentativas terapêuticas (CAPLAN, 2005). Neste trabalho avaliamos a utilização de duas fontes de células-tronco mesenquimais, a medula óssea e a polpa dentária, em um modelo ovino para osteonecrose da cabeça do fêmur, visando atender a essa necessidade de ensaios clínicos que viabilizem a utilização da terapia celular em humanos.

As células-tronco da polpa dentária humana são a nova promessa da terapia celular. Estas células foram isoladas e cultivadas por Gronthos et al. (2000) e extensivamente caracterizadas por Kerkis et al. (2006). No entanto, poucos ensaios clínicos foram realizados com essas células no campo da terapia celular e engenharia de tecidos.

Nossos achados histológicos sugerem uma maior recuperação tecidual com a utilização das células tronco-mesenquimais da polpa dentária no foco da lesão na cabeça do fêmur, e confirmam a viabilidade dessas células após transplante celular pela expressão da $\beta$-galactosidase nas células de medula óssea transduzidas. Esses achados em conjunto representam novidades no campo da terapia celular. Dados não conclusivos referentes ao achados de cromossomos humanos na cabeça de fêmur de ovinos submetidos ao transplante celular foram obtidos até o momento, deixando assim uma questão a ser respondida pelo grupo de pesquisadores, entretanto a marcação positiva macroscópica do osso regenerado por LACZ evidencia a eficiência da terapia celular. 


\section{CONCLUSÃO}

As MSC injetadas na cabeça do fêmur sobreviveram ao processo de transplante e proliferaram em pouco tempo, o que foi evidenciado pelo gene repórter LacZ expressando o $\beta$-Gal após fixação pelo X-Gal.

A descompressão central é uma técnica cirúrgica de fácil execução que pode servir como base para tentativas terapêuticas com célulastronco na ONCF em humanos, porém, ineficaz quando aplicada sozinha.

Os dados histológicos sugeriram uma regeneração óssea em tempo menor do animal submetido a transplante de células-tronco da polpa dentária, quando comparado ao animal submetido somente a descompressão central.

A terapia celular na osteonecrose da cabeça do fêmur pode ser um dos tratamentos conservativos mais indicados para esta doença. 


\section{REFERÊNCIAS}

BEJAR, J.; PELED, E.; BOSS, J. H. Vasculature deprivation - induced osteonecrosis of the rat femoral head as a model for therapeutic trials.

Theoretical Biology and Medical Modelling, v. 2, n. 24, 2005.

BEKLER, H.; UYGUR, A. M.; GÖKÇE, A.; BEYZADEOGLUT, T. The effect os steroid use on the pathogenesis of avascular necrosis of the femoral head: an animal model. Acta Orthopaedica et Traumatologica Turcica, $v$. 41, p. $58-63,2007$.

BIANCO, P.; RIMINUCCI, M.; GRONTHOS, S.; ROBEY, P. G. Bone marrow stromal stem cells: Nature, biology, and potential applications. Stem Cells, v. 19, p. 180-192, 2001.

BIANCO, P.; ROBEY, P. G. Marrow stromal stem cells. Journal of Clinical Investigation, v. 105, p. 1663-1668, 2000.

BIANCO, P.; ROBEY, P.G. Stem cells in tissue engineering. Nature, v. 414, p. 118-121, 2001.

BIANCO, P.; ROBEY, P. G.; SIMMONS, P. J. Mesenchymal stem cells: Revisiting history, concepts, and assays. Cell Stem Cell, v. 2, p. 313319, 2008.

BOSS, J. H.; MISSELEVICH, I. Osteonecrosis of the femoral head of laboratory animals: The lessons learned from a comparative study of osteonecrosis in man and experimental animals. Veterinary Pathology, v. 40, p. 345-354, 2003.

CANCEDDA, R.; BIANCHI, G.; DERUBEIS, A.; QUARTO, R.. Cell therapy for bone disease: A review of current status. Stem Cells, v. 21, p. 610-619, 2003a. 
CANCEDDA, R.; DOZIN, B.; GIANNONI, P.; QUARTO, R. Tissue engineering and cell therapy of cartilage and bone. Matrix Biology, $\mathrm{V}$. 22 , p. $81-91,2003$ b.

CAPLAN, A. I. Mesenchymal stem cells and gene therapy. Clinical Orthopaedics and Related Research, p.S67-S70, 2000.

CAPLAN, A. I. Mesenchymal stem cells: Cell-based reconstructive therapy in orthopedics. Tissue Engineering, v. 11, p. 1198-1211, 2005.

CHENG, E. Y.; THONGTRANGAN, I.; LAORR, A.; SALEH, K. J. Spontaneous resolution of osteonecrosis of the femoral head. Journal of Bone and Joint Surgery-American Volume, v. 86A, p. 2594-2599, 2004.

CHERIAN, S. F.; LAORR, A.; SALEH, K. J.; KUSKOWSKI, M. A.; BAILEY, R. F.; CHENG, E. Y.. Quantifying the extent of femoral head involvement in osteonecrosis. Journal of Bone and Joint Surgery-American Volume, v. $85 \mathrm{~A}$, p. $309-315,2003$.

CONZEMIUS, M. G.; BROWN, T. D.; ZHANG, Z. D.; ROBINSON, R. A.. A new animal model of femoral head osteonecrosis: one that progresses to human-like mechanical failure. Journal of Orthopaedic Research, $v$. 20, p. 303-309, 2002.

D'AQUINO, R.; PAPACCIO, G.; LAINO, G.; GRAZIANO, A. Dental pulp stem cells: a promising tool for bone regeneration. Stem cells Rewier, v. 4, p. 21-26, 2008.

Ficat, R. P. Idiopathic bone necrosis of the femoral-head - early diagnosis and treatment. Journal of Bone and Joint Surgery-British Volume, $v$. 67, p. 3-9, 1985.

FRIEDENSTEIN, A. J.; GORSKAJA, U. F.; KULAGINA, N. N. Fibroblast precursors in normal and irradiated mouse hematopoietic organs.

Experimental Hematology, v. 4, p. 267-274, 1976. 
GANGJI, V.; HAUZEUR, J. P.; MATOS, C.; DE MAERTELAER, V.; TOUNGOUZ, M.; LAMBERMONT, M. Treatment of osteonecrosis of the femoral head with implantation of autologous bone-marrow cells - A pilot study. Journal of Bone and Joint Surgery-American Volume, v. 86A, p. $1153-1160,2004$.

GANGJI, V.; MATOS, C.; LAMBERMONT, M.; APPELBOOM, T.; HAUZEUR, J. $P$. Autologous bone marrow transplantation and core decompression in the treatment of osteonecrosis of the femoral head. Arthritis and Rheumatism, v. 46, p. S227-S227, 2002.

GANGJI, V.; TOUNGOUZ, M.; HAUZEUR, J. P.. Stem cell therapy for osteonecrosis of the femoral head. Expert Opinion on Biological Therapy, v. 5, p. 437-442, 2005.

GANGJI, V.; TOUNGOUZ, M.; LAMBERMONT, M.; BASTIANELLI, E.; HAUZEUR, J.. Treatment of osteonecrosis of the femoral head with implantation of autologous bone-marrow cells: Five-year follow-up. Bone, v. 40, p. S46-S47, 2007.

GARDENIERS, J. V. M.. ARCO committee on terminology and staging (report on the committee meeting at Santiago De Compostela). ARCO Newsletter, v. 5, p. 79-82, 1993.

GRONTHOS, S.; BRAHIM, J.; LI, W.; FISHER, L. W.; CHERMAN, N.; BOYDE, A.; DENBESTEN, P.; ROBEY, P. G.; SHI, S. Stem cell properties of human dental pulp stem cells. Journal of Dental Research, v. $81, p$. 531-535, 2002.

GRONTHOS, S.; MANKANI, M.; BRAHIM, J.; ROBEY, P. G.; SHI, S.. Postnatal human dental pulp stem cells (DPSCs) in vitro and in vivo. Proceedings of the National Academy of Sciences of the United States of America, v. 97, p. 13625-13630, 2000.

HANNOUCHE, D.; RAOULD, A.; NIZARD, R. S.; SEDEL, L.; PETITE, H.. Embedding of bone samples in methylmethacrylate: A suitable method for tracking LacZ mesenchymal stem cells in skeletal tissues. Journal of Histochemistry \& Cytochemistry, v. 55, p. 255-262, 2007. 
HASSAN, H. T.; EL-SHEEMY, M. Adult bone-marrow stem cells and their potential in medicine. Journal of the Royal Society of Medicine, v. 97, p. 465-471, 2004.

HAUZEUR, J. P.; PASTEELS, J. L.; SCHOUTENS, A.; HINSENKAMP, M.; APPELBOOM, T.; CHOCHRAD, I.; PERLMUTTER, N.. The diagnostic-value of magnetic-resonance imaging in non-traumatic osteonecrosis of the femoral-head. Journal of Bone and Joint Surgery-American Volume, v. $71 \mathrm{~A}$, p. 641-649, 1989.

HERNIGOU, P.; BEAUJEAN, F.; LAMBOTTE, J. C. Decrease in the mesenchymal stem-cell pool in the proximal femur in corticosteroidinduced osteonecrosis. Journal of Bone and Joint Surgery-British Volume, v. 81B, p. 349-355, 1999.

HERNIGOU, P.; BERNAUDIN, F.; REINERT, P.; KUENTZ, M.; VERNANT, J. $P$.. Bone-marrow transplantation in sickle-cell disease - Effect on osteonecrosis: A case report with a four-year follow-up. Journal of Bone and Joint Surgery-American Volume, v. 79A, p. 1726-1730, 1997.

HUFFMAN, K. M.; BOWERS, J. R.; DAILIANA, Z.; HUEBNER, J. L.; URBANIAK, J. R.; KRAUS, V. B. Synovial fluid metabolites in osteonecrosis. Rheumatology, v. 46, p. 523-528, 2007.

ISRAELITE, C.; NELSON, C. L.; ZIARANI, C. F.; ABBOUD, J. A.; LANDA, J. ; STEINBERG, M. E. Bilateral core decompression for osteonecrosis of the femoral head. Clinical Orthopaedics and Related Research, p. 285290, 2005.

KERKIS, I.; AMBRÓSIO, C. E.; KERKIS, A.; MARTINS, D. S.; ZUCCONI, E.; FONSECA, S. A. S.; CABRAL, R. M.; MARANDUBA, C. M. C.; GAIAD, T. P.; MORINI, A. C.; VIEIRA, N. M.; BRÓLIO, M. P.; SANT'ANNA, O. A.; MIGLINO, M. A.; ZATZ, M. Early transplantation of human immature dental pulp stem cells from baby teeth to golden retriever muscular dystrophy (GRMD) dogs: local or systemic? Journal of Translational Medicine, v. 6, p. 36, 2008. 
KERKIS, I.; KERKIS, A.; DOZORTSEV, D.; STUKART-PARSONS, G. C. ; MASSIRONI, S. M. G.; PEREIRA, L. V.; CAPLAN, A. I.; CERRUTI, H. F. Isolation and characterization of a population of immature dental pulp stem cells expressing OCT-4 and other embryonic stem cell markers. Cells Tissues Organs, v. 184, p. 105-116, 2006.

KIM, S.-K.; BAHK, W.-J.; CHANG, C.-H.; JANG, J.-D.; SHUL, K.-H. Treatment of osteonecrosis of the femoral head using autologous cultured osteoblasts: a case report. Journal of Medical Case Reports, v. 2, 2008.

KIRKER-HEAD, C. A.; GERHART, T. N.; ARMSTRONG, R.; SCHELLING, S. H.; CARMEL, L. A. Healing bone using recombinant human bone morphogenetic protein 2 and copolymer. Clinical Orthopaedics and Related Research, p. 205-217, 1998.

KON, E.; MURAGLIA, A.; CORSI, A.; BIANCO, P.; MARCACCI, M.; MARTIN, I.; BOYDE, A.; RUSPANTINI, I.; CHISTOLINI, P.; ROCCA, M.; GIARDINO, R.; CANCEDDA, R.; QUARTO, R. Autologous bone marrow stromal cells loaded onto porous hydroxyapatite ceramic accelerate bone repair in critical-size defects of sheep long bones. Journal of Biomedical Materials Research, v. 49, p. 328-337, 2000.

KOO, K. H.; KIM, R.; KIM, Y. S.; AHN, I. O.; CHO, S. H.; SONG, H. R.; PARK, Y. S.; KIM, H.; WANG, G. J. Risk period for developing osteonecrosis of the femoral head in patients on steroid treatment. Clinical Rheumatology, v. 21, p. 299-303, 2002.

LEE, H. S.; HUANG, G. T.; CHIANG, H. S.; CHIOU, L. L.; CHEN, M. H.; HSIEH, C. H.; JIANG, C. C.. Multipotential mesenchymal stem cells from femoral bone marrow near the site of osteonecrosis. Stem Cells, v. 21, p.190-199, 2003.

LINDROOS, B.; MÄENPÄÄ, K.; YLIKOMI, T.; OJA, H.; SUURONEN, R.; MIETTINEN, S. Characterisation of human dental stem cells and buccal mucosa fibroblasts. Biochemical and Biophysical Research

Communications, v. 368, p. 329-335, 2008. 
MAGNUSSEN, R. A.; GUILAK, F.; VAIL, T. P. Articular cartilage degeneration in post-collapse osteonecrosis of the femoral head Radiographic staging, macroscopic grading, and histologic changes. Journal of Bone and Joint Surgery-American Volume, v. 87A, p. 1272-1277, 2005.

MANGGOLD, J.; SERGI, C.; BECKER, K.; LUKOSCHEK, M.; SIMANK, H. G. A new animal model of femoral head necrosis induced by intraosseous injection of ethanol. Laboratory Animals, v. 36, p. 173-180, 2002.

MARCINIAK, D.; FUREY, C.; SHAFFER, J. W. Osteonecrosis of the femoral head - A study of 101 hips treated with vascularized fibular grafting. Journal of Bone and Joint Surgery-American Volume, v. 87A, p. 742-747, 2005.

MONT, M. A.; MARULANDA, G. A.; JONES, L. C.; SALEH, K. J.; GORDON, N.; HUNGERFORD, D. S.; STEINBERG, M. E. Systematic analysis of classification systems for osteonecrosis of the femoral head. Journal of Bone and Joint Surgery-American Volume, v. 88A, p. 16-26, 2006.

MRUGALA, D.; BONY, C.; JORGENSEN, C.; NOEL, D. Characterization of ovine mesenchymal stem cells from bone marrow: Application for the development of a cartilage repair model. Annals of the Rheumatic Diseases, v.67, p.A47-A48, 2008a.

MRUGALA, D.; BONY, C.; NEVES, N.; CAILLOT, L.; FABRE, S.; MOUKOKO, D.; JORGENSEN, C.; NOEL, D. Phenotypic and functional characterisation of ovine mesenchymal stem cells: application to a cartilage defect model. Annals of the Rheumatic Diseases, v.67, p.288-295, 2008b.

OTAKI, S.; UESHIMA, S.; SHIRAISHI, K.; SUGIYAMA, K.; HAMADA, S.; YORIMOTO, M.; MATSUO, O. Mesenchymal progenitor cells in adult human dental pulp and their ability to form bone when transplanted into immunocompromised mice. Cell Biology International, v. 31, p.11911197, 2007. 
PERRY, B. C.; ZHOU, D.; WU, X. H.; YANG, F. C.; BYERS, M. A.; CHU, T. M. G.; HOCKEMA, J. J.; WOODS, E. J.; GOEBEL, W. S. Collection, cryopreservation, and characterization of human dental pulp-derived mesenchymal stem cells for banking and clinical use. Tissue Engineering Part C-Methods, p. 14, p. 149-156, 2008.

PITTENGER, M. F.; MACKAY, A. M.; BECK, S. C.; JAISWAL, R. K.; DOUGLAS, R.; MOSCA, J. D.; MOORMAN, M. A.; SIMONETTI, D. W.; CRAIG, S.; MARSHAK, D. R. Multilineage potential of adult human mesenchymal stem cells. Science, v. 284, p. 143-147, 1999.

PROCKOP, D. J. Marrow stromal cells as steam cells for nonhematopoietic tissues. Science, v. 276, p. 71-74, 1997.

STEINBERG, M. E.; HAYKEN, G. D.; STEINBERG, D. R. A quantitative system for staging avascular necrosis. Journal of Bone Joint Surgery British, v. 77, p. 34-41, 1995.

SUGANO N, A. T.; OHZONO, K.; KUBO, T.; HOTOKEBUCHI, T.; TAKAOKA, $\mathrm{K}$. The 2001 revised criteria for diagnosis, classification, and staging of idiopathic osteonecrosis of the femoral head. Journal of Orthopaedic Science, v. 7, p. 601-605, 2002.

UEBLACKER, P.; WAGNER, B.; VOGT, S.; SALZMANN, G.; WEXEL, G.; KRUEGER, A.; PLANK, C.; BRILL, T.; SPECHT, K.; HENNIG, T.; SCHILLINGER, U.; IMHOFF, A. B.; MARTINEK, V.; GANSBACHER, B. In vivo analysis of retroviral gene transfer to chondrocytes within collagen scaffolds for the treatment of osteochondral defects. Biomaterials, v. 28, p. 4480-4487, 2007.

WANG, C. J.; WANG, F. S.; HUANG, C. C.; YANG, K. D.; WENG, L. H.; HUANG, H. Y. Treatment for osteonecrosis of the femoral head:

Comparison of extracorporeal shock waves with core decompression and bone-grafting. Journal of Bone and Joint Surgery-American Volume, v. 87 A, p. $2380-2387,2005$.

YOON, T. R.; ROWE, S. M.; SONG, E. K.; MULYADI, D. Unusual osteonecrosis of the femoral head misdiagnosed as a stress fracture. Journal of Orthopaedic Trauma, v. 18, p. 43-47, 2004. 
YOON, T. R.; SONG, E. K.; ROWE, S. M.; PARK, C. H. Failure after core decompression in osteonecrosis of the femoral head. International Orthopaedics, v. 24, p. 316-318, 2001. 